\title{
GUIDELINES FOR THE PRODUCTION OF \\ PLANTING MATERIAL \\ FOR RESTORATION
}

\section{OF-RIPARIAN}

FORESTS

R.

if $1(1)(3)$

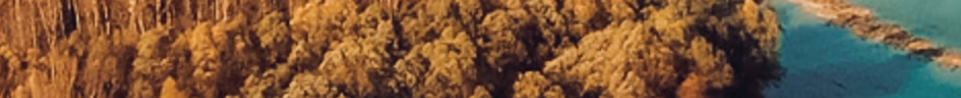
1.10.t. (1)

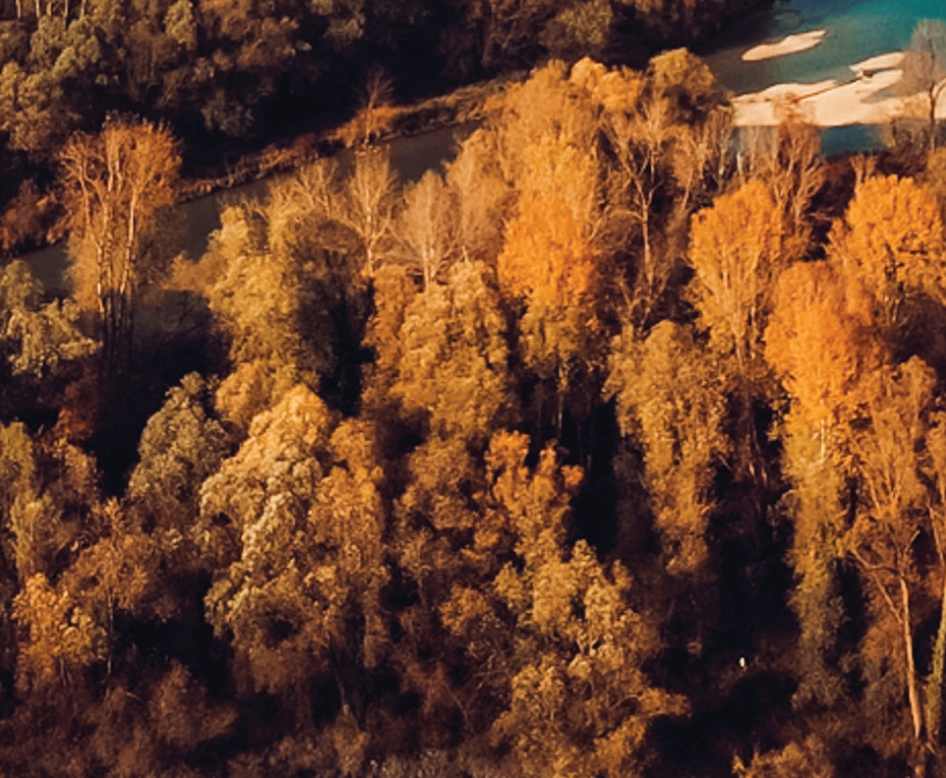




\section{GUIDELINES FOR THE \\ PRODUCTION OF \\ PLANTING MATERIAL \\ FOR RESTORATION OF \\ RIPARIAN FORESTS}

Ljubljana, 2021 


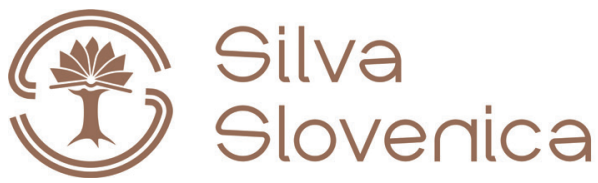

Studia Forestalia Slovenica, 170

ISSN 0353-6025

ISBN 978-961-6993-64-7

Publisher: Slovenian Forestry Institute, Silva Slovenica publishing centre, Ljubljana, 2021

Title: Guidelines for the production of planting material for restoration of riparian forests

Editors: Marjana Westergren, Gregor Božič

Technical editors: Silvija Krajter Ostoić, Peter Železnik

Language editor: Ad Litteram

Design and print: Klinger d.o.o.

Edition: $1^{\text {st }}$ Edition

Price: Free

Circulation: 150

Electronic issue: http://dx.doi.org/10.20315/SFS.170

Funding: Resilient riparian forests as ecological corridors in the Mura-Drava-Danube Biosphere Reserve (DTP2-044-2.3 - REFOCuS). The project was co-funded by European Union funds (ERDF, IPA).

\section{(ㄷ) (1) (요 $\Theta$}

Guidelines for the production of planting material for restoration of riparian forests is licensed under a Creative Commons Attribution 4.0 International License.

Disclaimer: The contents and views presented in this handbook are the sole responsibility of the authors and not of the Interreg Danube Transnational Programme or European Commission.

CIP - Kataložni zapis o publikaciji

Narodna in univerzitetna knjižnica, Ljubljana

$630 * 232: 630 * 26(035)$

GUIDELINES for the production of planting material for restoration of riparian forests / [authors Gregor Božič ... [et al.] ; editors Marjana Westergren, Gregor Božičc. - 1st ed. - Ljubljana : Slovenian Forestry Institute, Silva Slovenica Publishing Centre, 2021. - (Studia Forestalia Slovenica, ISSN 0353-6025 ; 170)

ISBN 978-961-6993-64-7

COBISS.SI-ID 55724291 
Authors:

Gregor Božič, Slovenian Forestry Institute, Ljubljana, Slovenia Marjana Westergren, Slovenian Forestry Institute, Ljubljana, Slovenia

Heino Konrad, Austrian Research Centre for Forests BFW, Vienna, Austria

Miran Lanšćak, Croatian Forest Research Institute, Jastrebarsko, Croatia

László Nagy, University of Sopron, Forest Research Institute, Sárvár, Hungary

Zoran Novčić, Institute of Lowland Forestry and Environment, University of Novi Sad, Novi Sad, Serbia

Sonja Rukavina, Hrvatske šume d.o.o., Zagreb, Croatia

Silvio Schüler, Austrian Research Centre for Forests BFW, Vienna, Austria

Srdjan Stojnić, Institute of Lowland Forestry and Environment, University of Novi Sad, Novi Sad, Serbia

Peter Železnik, Slovenian Forestry Institute, Ljubljana, Slovenia

Data contributors:

Mitja Černela, Gozdarstvo Turnišče, Murska Sobota, Slovenia

Franc Kreft, Trgovina z lesom Franc Kreft s.p., Murska Sobota, Slovenia

Janez Kolenko, Arboris Janez Kolenko s.p. and BLS Gozd d.o.o., Lendava, Slovenia

Marija Herman-Planinšek, Drevesnica Omorika, Muta, Slovenia

Vlado Planinšek, Drevesnica Omorika, Muta, Slovenia

Josef Schwanzer, Baumschule Schwanzer Ges.m.b.H., Langenschönbichl, Austria

Cover photos:

Front cover - REFOCuS promotion video

Back cover - Gregor Božič, REFOCuS promotion video 


\section{Contents}

1. Background $\ldots \ldots \ldots \ldots \ldots \ldots \ldots \ldots \ldots \ldots \ldots \ldots \ldots \ldots$

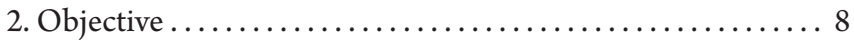

3. Small-size forest nurseries in their own words.......... 9

3.1 Supply and demand of forest reproductive material for riparian tree species on the market.............. 9

3.2 Market for regional (small-size) forest nurseries ....... 9

3.3 Investment in new technologies and machinery ...... 10

3.4 Nursery establishment costs . .............. 10

3.5 Perspectives and obstacles $\ldots \ldots \ldots \ldots \ldots \ldots \ldots \ldots 1$

4. General guidelines for producing planting material. ...... 12

4.1 Basic material selection................... 12

4.2 Collection of forest reproductive material......... 13

4.3 Seed handling and processing $\ldots \ldots \ldots \ldots \ldots \ldots \ldots 18$

4.4 Seed storage ............................. 19

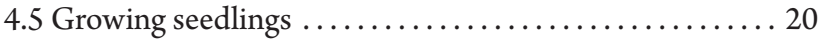

4.6 Transporting seedlings $\ldots \ldots \ldots \ldots \ldots \ldots \ldots \ldots \ldots \ldots$

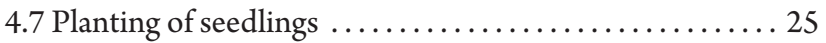

5. Protocols for seedling production of main riparian tree species $\ldots \ldots \ldots \ldots \ldots \ldots \ldots \ldots \ldots \ldots$

5.1 Alnus glutinosa (L.) Gaertn., black alder............ 28

5.1.1 Production of black alder seedlings using hydroponic technology .................... 29

5.2 Fraxinus angustifolia Vahl. and Fraxinus excelsior L., narrow-leaved and common ash .................. 33

5.3 Populus nigra L., European black poplar............ 36

5.5 Quercus robur L., pedunculate oak .............. 41

5.6 Ulmus laevis Pall. and Ulmus minor Mill.,

European white elm and field elm............... 44

6. List of forest nurseries producing forest reproductive material for riparian forests of the Mura-Drava-Danube Biosphere Reserve ........... 46

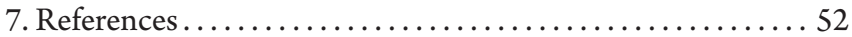




\section{Background}

Riparian forests are among the most dynamic and threatened forests in Europe. In the Mura-Drava-Danube Biosphere Reserve they are managed in different ways, ranging from no management, conservative management for nature conservation, sustainable management for all ecosystem services, intensive short-rotation and monoculture forestry focused on the production of large amounts of timber or energy-related biomass. The current composition and structure of riparian forests reflects a variety of historical and recent anthropogenic disturbances. Land use changes have resulted in remarkable reduction and fragmentation of forest cover. Altered frequency, duration and/or intensity of flooding, a lowered floodplain water table and changes in alluvial deposition regimes and patterns, the introduction of new pests, diseases and invasive plant species have all contributed to changes in the size, tree species composition and health of riparian forests. Natural regeneration of riparian forests is often impaired or even impossible because of the large-scale presence of very dense ground cover vegetation, which may prevent regeneration from seed. Alternatively, the process may take too long in an occasionally flooded terrain. Therefore, natural regeneration of riparian forests is often complemented by:

- artificial regeneration of old riparian forest stands

- the restoration of riparian forest stands destroyed by disturbances such as diseases, pests, windthrow or clearcutting

- establishment of new planted riparian forests on bare areas, for example for plantation conversions or where forest vegetation is lacking.

In addition to supporting natural regeneration, identifying and using appropriate native tree species material to plant in riparian forests is the best pro-active way to maintain or build resilience in these forests. Although native riparian tree species are under severe environmental pressure and are in decline, the introduction of non-native species is not recommended due to a lack of scientific background. Instead, the use of existing intraspecific genetic diversity of native riparian tree species is a reasonable and legitimate alternative. The use of site adapted (or pre-adapted) seed or planting material with high genetic diversity, high quality and increased tolerance/resistance to biotic or abiotic stress is considered the primary option for artificial regeneration, afforestation or habitat reconstruction. 
The likelihood of successful artificial regeneration depends on:

- $\quad$ ensuring high-quality forest reproductive material through appropriate selection of seed sources, seed collection and processing

- good nursery practices leading to high-quality seedlings

- the combination of seedling quality and the level of environmental stressors, such as drought, groundwater levels, frequency and duration of flooding, and biotic agents

- the size of the planting area, where larger areas are preferred but they should not be larger than a few hectares (areas less than one hectare in size are suitable for colonization by invasive vegetation)

- site conditions

- $\quad$ practices used for site preparation

- a good knowledge of population genetics, ecophysiology and biology

- appropriate planning of planting

- use of appropriate planting techniques

- weather conditions (including climatic conditions)

- fencing of regeneration areas to prevent browsing of seedlings by game

- vegetation control such as removal of weeds and competing vegetation or mowing

- $\quad$ assisting the growth and development of seedlings through soil preparation and removal of vegetation adjacent to the seedlings

- $\quad$ supporting natural regeneration of admixed tree species in a way not to damage the planted seedlings

- protection after planting (early detection of symptoms of pests and diseases and individual stem protection)

- monitoring reforestation and afforestation success and learning from failures.

Non-native tree species should only be planted if they are not invasive and in situations where this is an economic necessity or as insurance when all native tree species are unsuccessful. These tree species can only be planted if permitted by relevant forestry and conservation legislation. Any decision to plant non-native tree species should be taken carefully, must be well planned and the measures must be monitored.

Both natural and artificial forest regeneration are important in riparian forests of the Mura-Drava-Danube Biosphere Reserve. According to an expert estimate within the Interreg Danube project REFOCuS, natural regeneration predominates in Serbia 
(64\%) and Croatia (80\%), while in Hungary, Slovenia and Austria artificial regeneration is more widespread, accounting for $80 \%$, $75 \%$ and $60 \%$ of forest regeneration in the biosphere reserve. These figures are strongly driven by the predominant forest types and the corresponding regeneration techniques. Natural regeneration works best with oak and willows but has less success for other riparian tree species. 


\section{Objective}

These guidelines aim to provide guidance on the selection of seed sources, seed collection and processing, promotion of genetic diversity and good nursery conditions for the production of forest reproductive material, i.e. seeds, plant parts and plants in riparian forests. Using the advice provided will ensure sustainable artificial regeneration, that is as close as possible to the natural one. The guidelines are based on the intersection of scientific knowledge and many years of experience from forest nurseries producing forest reproductive material of riparian tree species.

The guidelines also give a unique insight into the forest nursery sector in the Mura-Drava-Danube Biosphere Reserve: their development, production costs, daily work, and current problems.

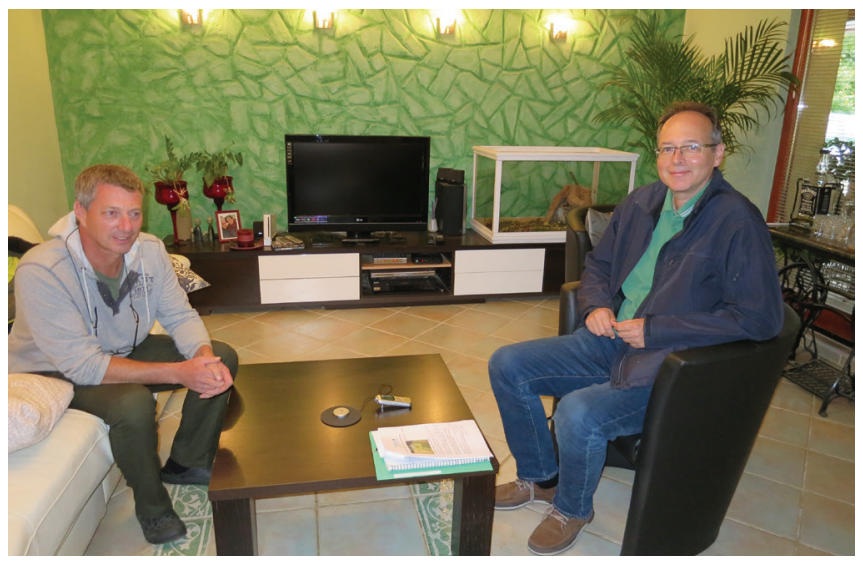

An interview at a Slovenian nursery Arboris (photo: A. Kolenko) 


\section{Small-size forest nurseries in their own words}

\subsection{Supply and demand of forest reproductive material for riparian tree species on the market}

The demand for forest reproductive material on the market in and around the Mura-Drava-Danube Biosphere Reserve is mostly for native tree species of good quality and larger seedlings. The bestselling seedlings are from 50 to 80 and from 80 to $120 \mathrm{~cm}$ tall. The demand for seedlings of riparian tree species has grown in recent years and continues to increase, mainly due to the dieback of Norway spruce (Picea abies), black alder (Alnus glutinosa), and common (Fraxinus excelsior) and narrow-leaved ash (F. angustifolia).

Forest nurseries have found that increased timber harvests in the forest, especially clearcuts, lead to higher demand for seedlings.

Because the demand for native tree species is the greatest, nurseries in and around the Mura-Drava-Danube Biosphere Reserve and those that supply plants to the Mura-Drava-Danube Biosphere Reserve are promoting regional plant collections. However, a significant increase in interest in seedlings of black walnut (Juglans nigra) has also been observed by the nurseries.

\subsection{Market for regional (small-size) forest nurseries}

Nurseries report that the main market for small size nurseries like those in and around the Mura-Drava-Danube Biosphere Reserve is the home country. Mostly, large forest owners and state forest services' buy the seedlings produced.

Most of the seed for producing plants is collected locally. Only when there is a shortage of local seed do nurseries import it.

Depending on the species, nurseries can produce seedlings of the genera Salix, Populus, Alnus and Fraxinus in one to two years. The taller the seedlings, the higher their price. Seedlings of pedunculate oak can be bought in the following height classes (in cm): $15 / 30,30 / 50,50 / 80,80 / 120,120 / 150,150 / 200$ while seedlings of black poplar can be found in height classes $80 / 120$, $120 / 200,150 / 200$ and $200 /+$ and for willows the height classes are: $120 / 200,150 / 200,200 / 250,250 / 300,300 /+$. The classes

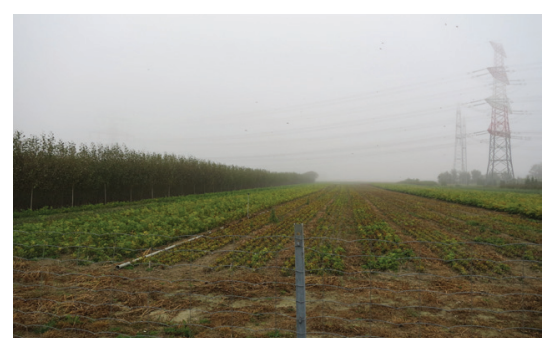

Plant production area in Schwanzer forest tree nursery, Austria (Photo: G. Božič)

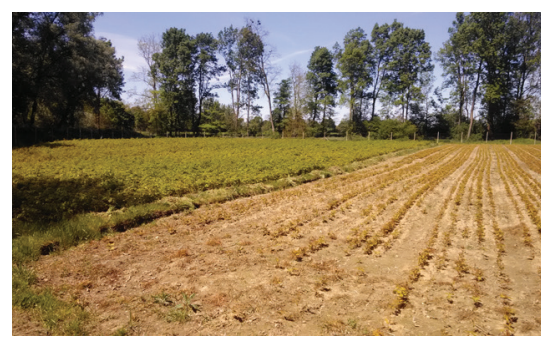

Plant production area in Gozdarstvo Turnišče forest nursery, Slovenia (Photo: M. Černela)

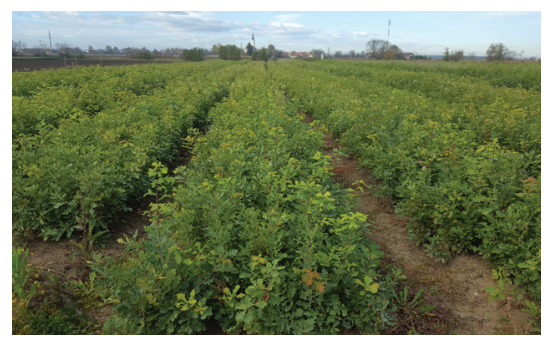

Plant production area in Limbuš forest nursery, Croatia (Photo: M. Lanšćak) 
can be different in different countries of the Mura-Drava-Danube Biosphere Reserve.

Small-size nurseries are extremely adaptable and diversify their production to continue functioning. Sometimes they also plant the seedlings for the customers to earn extra income.

Despite their small-size, nurseries often produce more seedlings than they can sell because demand for different species varies from year to year.

\subsection{Investment in new technologies and machinery}

The highest cost in seedling production is the cost of manual labour, which is also physically demanding. Therefore, it is more economical to invest in machinery and new technology and reduce the cost of labour. However, nurseries need to maintain the machinery regularly and keep themselves updated with the latest technologies in order to constantly improve and cheapen the seedling production.

Based on the experience of nurseries, container seedlings work well for high altitude forests. However, they perform poorly in lowlands because the roots are often misshapen (grow in circles) and the substrate dries out too quickly if not planted properly.

\subsection{Nursery establishment costs}

The cost of establishing a nursery depends largely on the size desired and the equipment involved. Table 1 lists the equipment needed for an average small-size nursery and the approximate cost of that equipment and infrastructure. Besides the equipment and infrastructure, the most important cost is the manual labour.

Table 1: Equipment and infrastructure needed for an average small size nursery and approximate costs of different items in the region of the Mura-Drava-Danube Biosphere Reserve.

\begin{tabular}{|l|l|}
\hline Item & Cost (EUR) \\
\hline Tractor & 50,000 \\
\hline Different ploughs & 20,000 \\
\hline $\begin{array}{l}\text { Seed processing, transplanting, and lifting } \\
\text { machines }\end{array}$ & $150,000-200,000$ \\
\hline $\begin{array}{l}\text { Greenhouse facilities, buildings for } \\
\text { storage and cold storage halls }\end{array}$ & 500,000 \\
\hline
\end{tabular}


Modern machinery and equipment can increase efficiency and productivity in all phases of nursery operations without sacrificing quality or safety. Since investment costs are high, national and EU subsidies and grants are very important for the establishment of local, small size nurseries.

\subsection{Perspectives and obstacles}

Compared to large nurseries, small, often family-run nurseries are more adaptable in terms of producing seedlings of different tree species. They can also sell most or all of their seedlings in local or national markets, whereas larger nurseries rely mainly on exports to survive. Another advantage is that seeds are collected locally and therefore the seedlings produced are adapted to local conditions. However, they are also more vulnerable to large market fluctuations. Small nurseries are mainly interested in cooperating with forestry companies and public forestry services.

The open market with forest reproductive material (within the EU) brings an opportunity for small nurseries since there are always new buyers for their seedlings. On the other hand, large international nurseries, especially from countries with low labour costs, offer cheap seedlings and can put local, small nurseries out of business.

In the case of larger nurseries that have appropriate international connections, the proportion of targeted production for export increases. Seed is imported from abroad and seedlings produced from these seed lots are sold back to the country of origin.

Uncertainty about long-term seedling production is an important constraint for small nurseries; seedling production takes several years, while there are no guarantees whether seedlings will be purchased when they are ready for planting. If not, the seedlings have to be destroyed and the work was in vain.

Nurseries also find the regulations controlling forest reproductive material overly complicated and time-consuming to implement. 


\section{General guidelines for producing planting material}

The guidelines presented here are based on scientific recommendations, considering the current policy landscape, and are enriched by best practices of forest nurseries from the MuraDrava-Danube Biosphere Reserve. They are written with riparian tree species in mind.

\subsection{Basic material selection}

Trees from which forest reproductive material may be obtained are called basic material. There are several types of basic material, which relate to different categories of forest reproductive material (Table 2).

Table 2: Categories of forest reproductive material in which the various types of basic material may be certified when fulfilling the respective requirements

\begin{tabular}{|c|c|c|c|c|c|}
\hline \multirow{2}{*}{$\begin{array}{l}\text { Type of basic } \\
\text { material }\end{array}$} & \multirow{2}{*}{ Description of the type } & \multicolumn{4}{|c|}{ Forest reproductive material category } \\
\hline & & $\begin{array}{l}\text { Source } \\
\text { Identified }\end{array}$ & Selected & Qualified & Tested \\
\hline Seed source & $\begin{array}{l}\text { Trees within an area from which seeds are } \\
\text { collected }\end{array}$ & $\mathrm{X}$ & - & - & - \\
\hline Seed stand & $\begin{array}{l}\text { A delineated population of trees possessing } \\
\text { sufficient uniformity }\end{array}$ & $\mathrm{X}$ & $\mathrm{X}$ & - & $\mathrm{X}$ \\
\hline Seed orchard & $\begin{array}{l}\text { A plantation of selected individuals in which } \\
\text { each individual is identified by a clone, family or } \\
\text { provenance. The plantation is isolated to avoid } \\
\text { non-native pollen and is managed to produce } \\
\text { frequent, abundant, and easily harvested seed } \\
\text { crops }\end{array}$ & - & - & $\mathrm{X}$ & $\mathrm{X}$ \\
\hline $\begin{array}{l}\text { Parents of } \\
\text { family/families }\end{array}$ & $\begin{array}{l}\text { Trees used to obtain progeny by controlled } \\
\text { or open pollination of one identified parent } \\
\text { used as female, with the pollen of one parent } \\
\text { (full-sibling) or a number of identified or } \\
\text { unidentified male parents (half-sibling) }\end{array}$ & - & - & $\mathrm{X}$ & $\mathrm{X}$ \\
\hline Clone & $\begin{array}{l}\text { Individuals (ramets) derived from a single } \\
\text { individual (ortet) by using vegetative } \\
\text { propagation (i.e., cuttings, micropropagation, } \\
\text { grafts, layers, etc.) }\end{array}$ & - & - & $\mathrm{X}$ & $\mathrm{X}$ \\
\hline Clonal mixture & $\begin{array}{l}\text { A mixture of initially identified clones in a } \\
\text { defined proportion }\end{array}$ & - & - & $\mathrm{X}$ & $\mathrm{X}$ \\
\hline
\end{tabular}


The type of basic material and the category of forest reproductive material depend on the intended use. No or very little phenotypic selection took place in the Source identified category of forest reproductive material. Selected forest reproductive material was phenotypically selected at the population level while Qualified forest reproductive material was selected at the individual level. Tested forest reproductive material proved to be genetically superior in comparative field trials. The higher the category, the more information is available on the quality and growth potential of forest reproductive material. However, this does not mean that the best we know is always the best we have.

\subsection{Collection of forest reproductive material}

The way seed is collected is crucial for the production of forest reproductive material categories Source identified and Selected. To safeguard genetic diversity, it is best to collect seed during full mast years when most trees in a stand have contributed to seed production. Consequently, seed lots collected at this time represent the genetic variation of the entire stand. We recommend collecting seed from at least 25 unrelated trees distributed throughout the seed stand. Equal amounts of seed should be collected from each tree. The higher the number of trees for seed collection, the better. Mixing seed lots can increase genetic diversity. It is usually allowed if the basic materials are from the same region of provenance and the process of mixing is documented.

When properly designed and containing sufficient genotypes (trees with different genetic makeup), seed orchards represent genetically diverse artificial populations of superior individuals (plus trees). These trees mate with each other and produce high quality seed. Seed orchards are established to propagate phenotypically superior trees to produce offspring with rapid growth, good form, or higher resistance to biotic or abiotic stress (called breeding orchards). They are also used to propagate scattered or endangered tree species that do not produce enough progeny in the forest (called ex situ gene conservation orchards). It is recommended to collect seeds in seed orchards in years when most genotypes have flowered. At least 20 clones must be harvested. This usually represents about half of the clones available. Approximately equal amounts of seed should be collected from each genotype.

Harvesting seeds from the ground is the easiest way to collect them. Heavy seeds or fruits from tree species such as oak, maple, chestnut, walnut, apple and pear can be collected manually, 
by raking, sweeping or with special vacuum cleaners. It is also possible to track down and use seed stocks prepared by various animals. However, the right timing of seed collection is critical. The first seeds to fall are usually dead or infected with insects or fungi and should not be collected.

Acorns are easy to collect but germinate very quickly when weather conditions are suitable. If the shoots of germinated acorns are no longer than $1 \mathrm{~cm}$, they can still be collected. Since acorns are sometimes heavily infested with insect larvae (especially from Balaninus species), the best way to test this is to soak them in water. This will expose the infested acorns because they float. Long-term storage of acorns is difficult, so it is best to sow them immediately after bringing them to a nursery. Floating acorns of oak species in water at $40^{\circ} \mathrm{C}$ for 3 hours and then drying and storing them at about $-3{ }^{\circ} \mathrm{C}$ is also practiced to allow sowing in spring thus avoiding damage by rodents over winter.

Seeds can also be harvested directly from the tree. This can be done by shaking the tree or branches, climbing, cutting off branches or felling the trees. Collecting seeds by climbing is one of the most dangerous tasks in forestry. There are various climbing techniques and special equipment that facilitate tree climbing. Collecting seeds from trees is mainly used for winged seeds (samaras) of species such as elms and maples.

Collecting seeds from felled trees risks reducing the number of parents below the desired level, as large numbers of trees are not usually felled solely for seed collection. It is best to harvest samaras from standing trees. The seed collectors spread tarpaulins under a tree, one person climbs the tree and beats the branches with a stick. On the ground, the leaves are manually separated from the fruits. Such fruits are ready for sowing. They can also be stored. For this purpose, they are further dried and put in plastic or jute bags. Collecting seeds from tall trees is difficult; therefore, smaller trees are often harvested or material from seed orchards is used.

Beating on branches is also used to harvest wild cherry fruit.

Alder seeds can be harvested from a water surface using nets and sieves. 


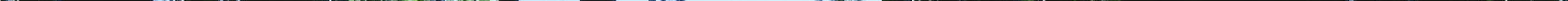


Table 3: Properties of seed for riparian forest tree species, time of collection and storage conditions

\begin{tabular}{|c|c|c|c|c|c|}
\hline Tree species & $\begin{array}{l}\text { Time for seed/ } \\
\text { fruit collection }\end{array}$ & $\begin{array}{l}\text { Colour of seed/ } \\
\text { fruit at collection }\end{array}$ & $\begin{array}{l}\text { Seed quantity } \\
{[\mathrm{kg}] \text { per } 100 \mathrm{~kg}} \\
\text { of fruit }\end{array}$ & $\begin{array}{l}\text { Number of seeds } \\
\text { perkg of seed }\end{array}$ & $\begin{array}{c}\text { Typical } \\
\text { germination } \\
\text { (average) [\%] }\end{array}$ \\
\hline Acer campestre & October & & & $12,000-25,000$ & $40-70(55)$ \\
\hline Alnus glutinosa & $\begin{array}{l}\text { September - } \\
\text { November }\end{array}$ & & 10.5 & $636,000-1,4 \times 10^{6}$ & $20-65(40)$ \\
\hline Alnus incana & $\begin{array}{l}\text { September - } \\
\text { October }\end{array}$ & & 12.5 & $1 \times 10^{6}-2 \times 10^{6}$ & $20-80(30)$ \\
\hline Carpinus betulus & $\begin{array}{l}\text { September - } \\
\text { December }\end{array}$ & $\begin{array}{l}\text { green-brown, } \\
\text { brown }\end{array}$ & 50 & $\begin{array}{c}\text { 14,000 - 19,000 } \\
\text { (with wings) }\end{array}$ & $50-70$ \\
\hline Fraxinus excelsior & August-October & $\begin{array}{l}\text { green-brown, } \\
\text { brown }\end{array}$ & & $9,000-26,000$ & $50-70$ \\
\hline $\begin{array}{c}\text { Fraxinus } \\
\text { angustifolia }\end{array}$ & August-October & yellow, brown & & $10,000-21,000$ & $50-70$ \\
\hline Malus sylvestris & autumn & yellow to red & $0.8-0.9$ & & $60-70$ \\
\hline Populus nigra & & & & & $67-100$ \\
\hline Prunus avium & summer & red, black & 8 & $4,800-6,500$ & $75-90$ \\
\hline Quercus robur & August-October & & & $130-290$ & 81 \\
\hline Salix spp. & & yellowish & & $1 \times 10^{6}-22 \times 10^{6}$ & $30-100$ \\
\hline Tilia cordata & after first frost & yellow brown & & $24,000-48,000$ & $40-50$ \\
\hline Ulmus glabra & & & & 36,000 & $61-80$ \\
\hline Ulmus laevis & May & yellow brown & 60 & 82,000 & $62-80$ \\
\hline Ulmus minor & & & & $80,000-160,000$ & $60-80$ \\
\hline
\end{tabular}




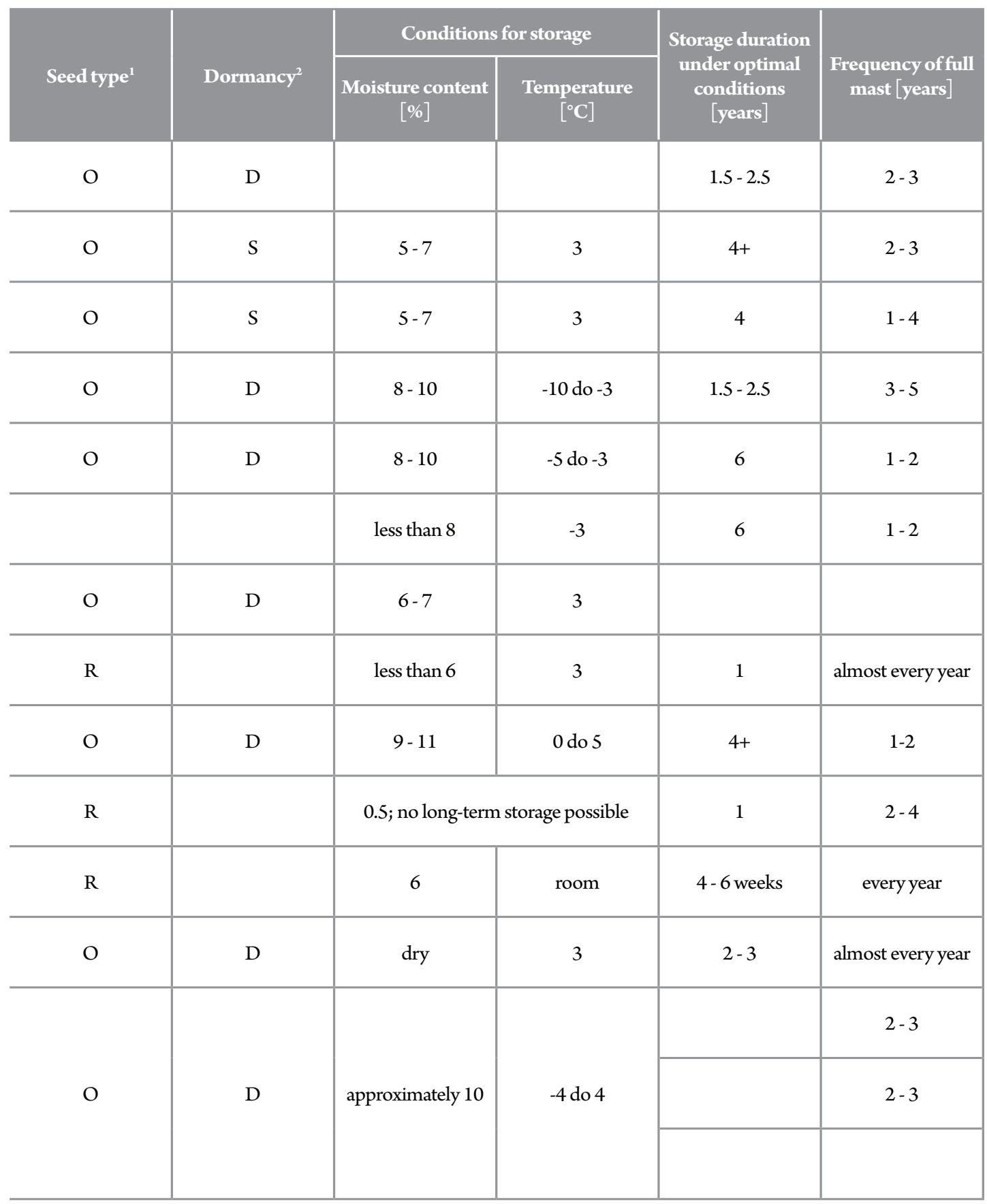




\subsection{Seed handling and processing}

After collecting forest reproductive material, the seeds should be extracted from the pods, conelets or fleshy fruits (e.g. apples, cherries). This is necessary to facilitate further processing and storage of seeds in a way that preserves their germination ability and allows for proper processing prior to sowing.

The most common method of seed extraction is extraction with drying. Fruits can be dried outdoors or in a seed dryer. In general, seeds of broadleaves should not be dried at temperatures above $20{ }^{\circ} \mathrm{C}$. After drying, seeds are cleaned of wings, husks, or other impurities if necessary.

Seeds from certain fruits such as hornbeam or walnut are extracted by threshing. Since manual threshing can be very time consuming and labour intensive, power-driven machines are used. A wide range of equipment is available for threshing grain, some of which can be adapted for tree seed extraction. Seed tolerance to threshing depends on the tree species, so machines must be carefully tested for adverse effects on each seed lot before the bulk of the seed is subjected to treatment.

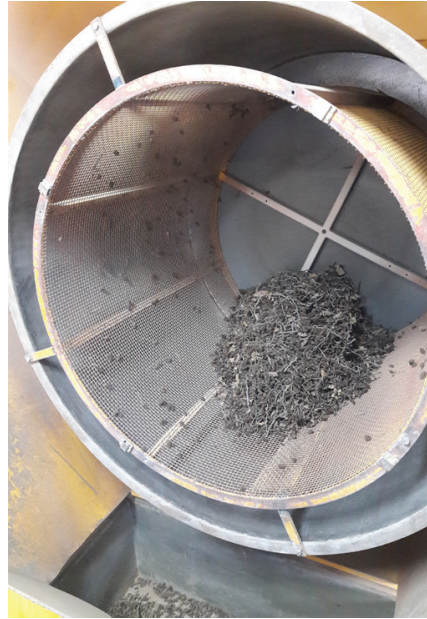

Extraction of black alder seeds with threshing using different machines in Croatian Forest Research Institute, Jastrebarsko, Croatia (Photo: M. Lanšćak)

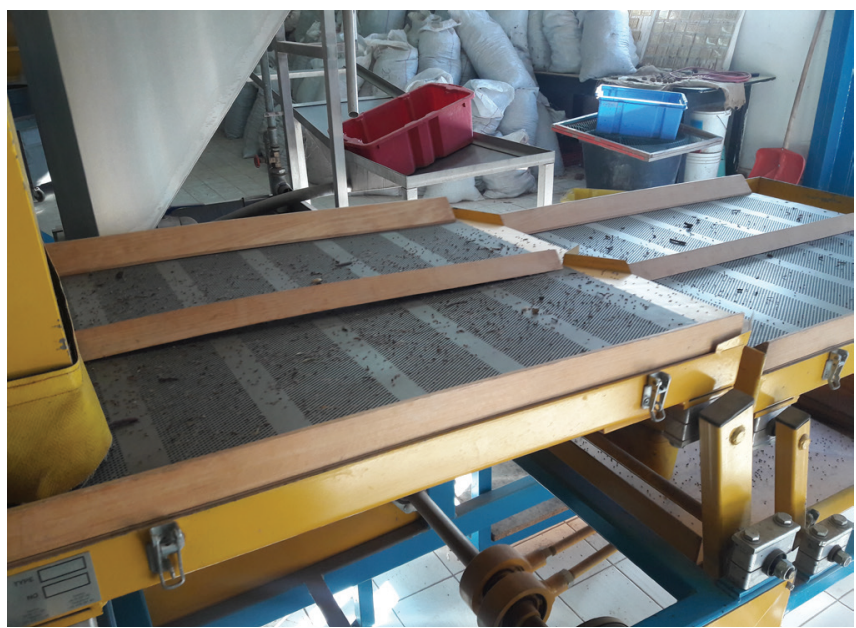

Fleshy fruits, such as cherries, should be macerated before storage or sown immediately, as the pulp begins to ferment very rapidly, which may greatly impair germination. The fruits are crushed or gently mashed and mixed with water. This usually allows the pulp and skins to be separated from the seeds by washing through a sieve to remove heavy material, and later by flotation in water to remove unwanted lighter impurities. This deboning should be done on the same day as the fruit collection. 
However, in Austria the fruits are soaked for two to three days and then the pulp is removed by high pressure water application. Since cherry seeds (pits) contain a lot of moisture, they should be dried in a shady, airy place for at least three weeks before storage. Otherwise, the seeds go to the nurseries for sowing immediately after soaking in water.

\subsection{Seed storage}

Seed storage is determined by seed type (orthodox or recalcitrant), decrease in seed viability during storage and dormancy.

Orthodox seed survives drying and/or freezing during ex situ conservation for longer periods of time. This is because the physiological processes of the seed and the growth of pathogenic fungi come to a complete halt. On the other hand, recalcitrant seeds are those that do not survive drying to a moisture content of less than $40 \%$ and freezing during ex situ conservation. These seeds cannot be stored for long periods like orthodox seeds as they lose their viability. When stored for shorter periods, they are kept at a temperature just above $0{ }^{\circ} \mathrm{C}$, where the physiological processes of pathogenic fungi and biochemical activity in the seeds are merely slowed down.

Seed dormancy is an evolutionary adaptation that prevents seeds from germinating in conditions unsuitable for seedling growth. Non-dormant seeds germinate when suitable temperature and moisture conditions are met. In contrast, dormant seeds will not germinate under favourable conditions until the cause of dormancy has been removed. These causes include hard seed coat, germination inhibitors, immaturity of seed embryo, impermeability of seed coat to water or oxygen, mechanically resistant seed coat, etc. More than half of the forest tree species have dormant seeds and dormancy is naturally eliminated under suitable conditions. The duration of dormancy also varies within the species, depending also on the provenance of the seed, i.e. its origin. In a controlled environment, we can eliminate dormancy in a process called stratification. Depending on the tree species, stratification can be simple or complex, but it always takes place in a humid environment with different temperatures. It allows for better germination compared to natural germination. Due to the usually expensive equipment needed for processing, stratification is suitable for large seed quantities. Different nurseries have different stratification protocols for seeds of the same tree species.

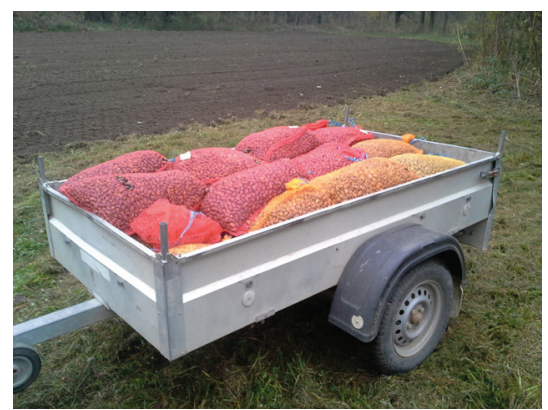

Transport of acorns to a nursery (Photo: M. Černela)

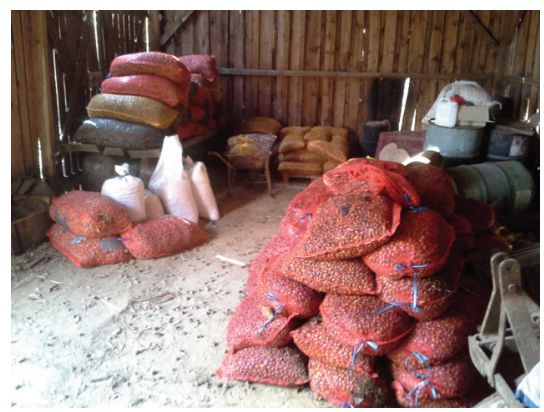

Storage of acorns in a nursery for autumn sowing (Photo: M. Černela)

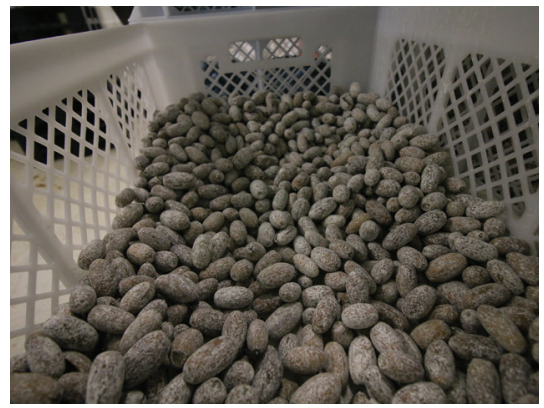

Storage of acorns, treated with fungicide over the winter at the gene bank in Croatian Forest Research Institute, Jastrebarsko, Croatia (Photo: M. Lanšćak) 


\subsection{Growing seedlings}

For the purpose of forest regeneration, three types of seedlings are used: bare-root seedlings, container seedlings and wildlings.

Growing bare-root seedlings is a complex multi-year process (usually four to five years), with each stage of work sequenced in the following order:

- $\quad$ soil preparation

- $\quad$ sowing of seed

- transplanting of seedlings and care for perennial seedlings

- excavation and preparation of the seedlings for planting in the field.

Soil preparation includes:

- $\quad$ sowing plants for green fertilization

- $\quad$ autumn ploughing

- fertilization

- harrowing or tilling the soil

- creation of seedbeds

- $\quad$ spraying with pesticides.

Seed sowing includes:

- analysis of seed purity and germination potential

- $\quad$ stratification (if necessary)

- disinfection and protection against rodents and birds

- $\quad$ sowing, covering, and rolling seeds

- $\quad$ irrigation and spraying with fungicides

- $\quad$ weeding

- additional fertilization

- overwintering.

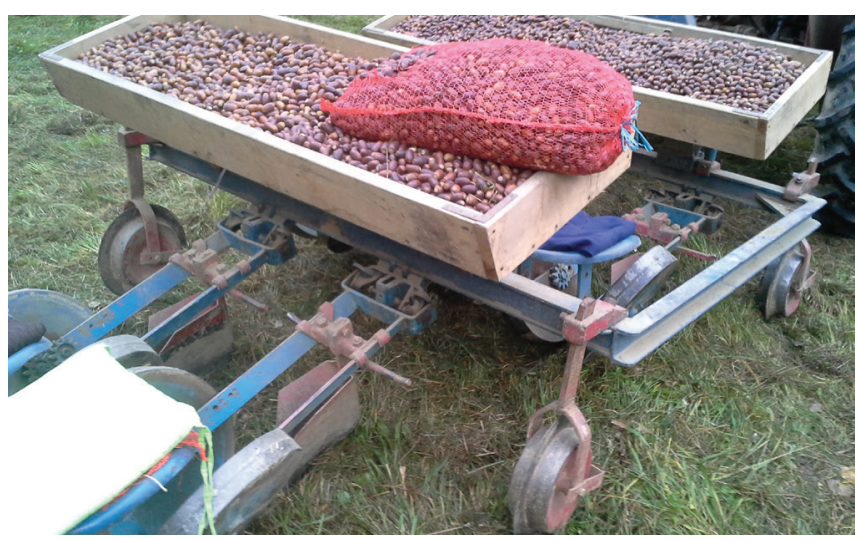

Loading of acorns into a modified plough prior to sowing (Photo: M. Černela) 


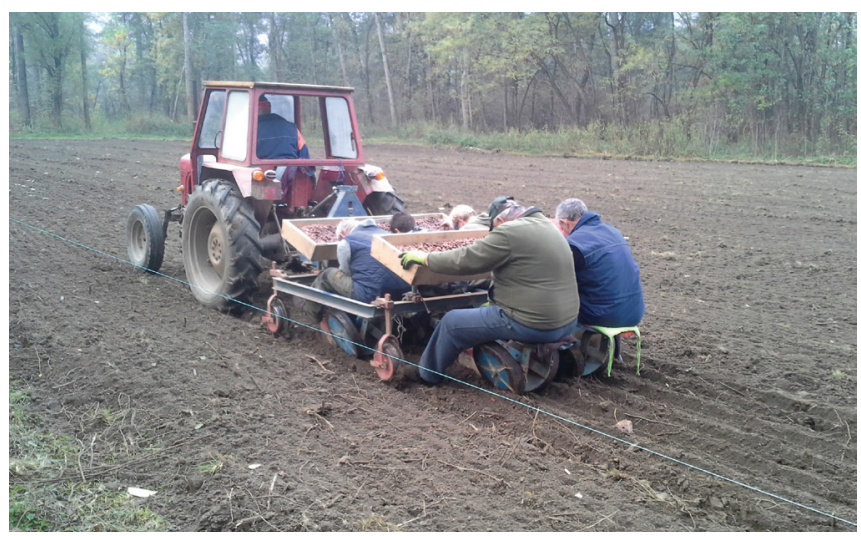

Sowing of acorns using a tractor and a modified plough, for which manual labour is essential (Photo: M. Černela)

A year or two after the germination of the seeds, the young plants are usually transplanted to a new planting bed. The process includes:

- $\quad$ spring fertilization (optional)

- $\quad$ weeding (it is done less frequently, as the seedlings are dense enough and cover the entire surface of the seedbed)

- $\quad$ watering the seedlings (only during prolonged dry periods)

- regular protection with fungicides.

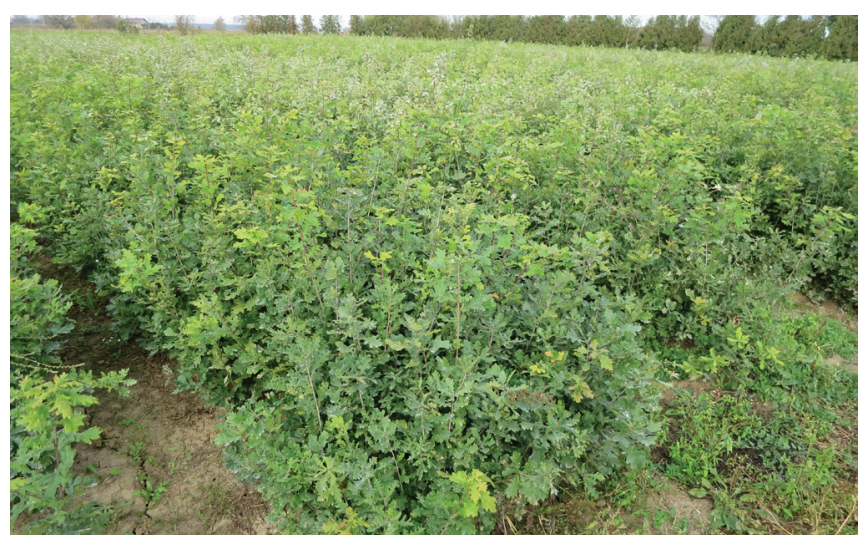

Bare-root seedlings of Quercus robur can grow from 60 to $100 \mathrm{~cm}$ tall during the first growing season (Photo: G. Božič)

Seedlings are transplanted in the spring. When transplanting them, we need to know what the target stock type of seedlings to be transplanted is. The number of seedlings per unit area depends on the stock type. Stock types are: $1+1,1+2,2+2,2+3$. " $1 / 2$ " or " $1+2$ " are the symbols that tell us the age of the seedling, namely: 
1 year before transplanting and 2 years after transplanting. The total age of the seedling in this case is 3 years. The aim of transplanting is to strengthen the root system and increase the height of the seedlings. Deciduous trees are transplanted after the first year. For most riparian tree species (Acer, Fraxinus, Malus, Quercus etc.) the best stock type is $1+2$. Type $1+1$ is more suitable only for Prunus and Alnus.

Wildlings are used when planting material of certain tree species and provenance is needed, but suitable seed has not been collected in sufficient quantity to raise seedlings in a nursery. This most often occurs with species that have sporadic mast years. Wildlings are collected in a forest at sites of known provenance or origin. The seedlings must be dug out of the ground with great care, transported to a nursery, and planted there. They must remain in a nursery for at least one year to recover from transplant shock.

Before the seedlings are transplanted into the forest, bare-root seedlings and wildlings must be dug up. This is usually done after the end of the vegetation period, after the seedlings have shed all their leaves. If the customer requires seedlings before this (during the vegetation period), they must be transported and planted immediately (within one day).

Container seedlings offer an alternative to bare-root seedlings, especially when short production times are required (e.g. shortage of bare-root seedlings), when planting is carried out outside the usual months or when unfavourable sites are to be planted. Production of container seedlings is generally shorter than bareroot seedling production and takes between one and two and a half years. The seedlings are grown in a controlled environment to achieve the desired maturity and quality. The content of nutrients in the growth substrate is very important. All this makes the production of container tree seedlings more demanding compared to the production of bare root seedlings. It is important to mention that the quality of the seedlings is highly dependent on the quality of the sown seeds. Since container seedlings are planted together with the growth substrate, they can be planted from spring to autumn, which is one of the biggest advantages of container seedlings. 


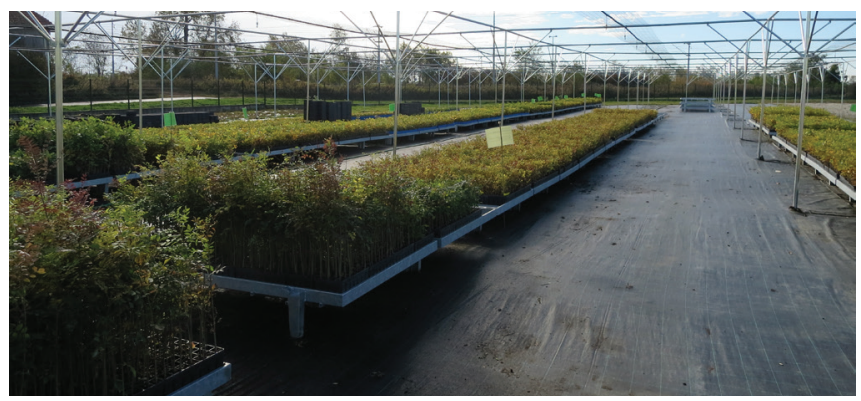

Production of container seedlings in forest nursery Drnje, Croatia (Photo: G. Božič)

\subsection{Transporting seedlings}

Before seedlings are planted in a forest, they must be transported from a nursery to the planting site. Rapid transportation and proper handling of the seedlings, ensuring that the roots remain moist during and after transportation, are critical to the success of artificial regeneration. Therefore, the date the seedlings are delivered to the planting site should also be the date they are loaded onto trucks in the nursery for transport.

The ability of seedlings to attach to available soil water through the roots depends on the water balance of the seedlings. Improper handling of seedlings leads to desiccation and drought stress in them, resulting in root rot, pest infestation, mould and disease, and consequently reduced seedling vitality. Therefore, forest seedlings must not be exposed to dry air, strong wind or direct sunlight during and after transport. Special transport bags are available for forest reproductive material.

All types of seedlings are more resistant to stress during transport when they are inactive. This means that it is best to transport and plant seedlings before they flush.

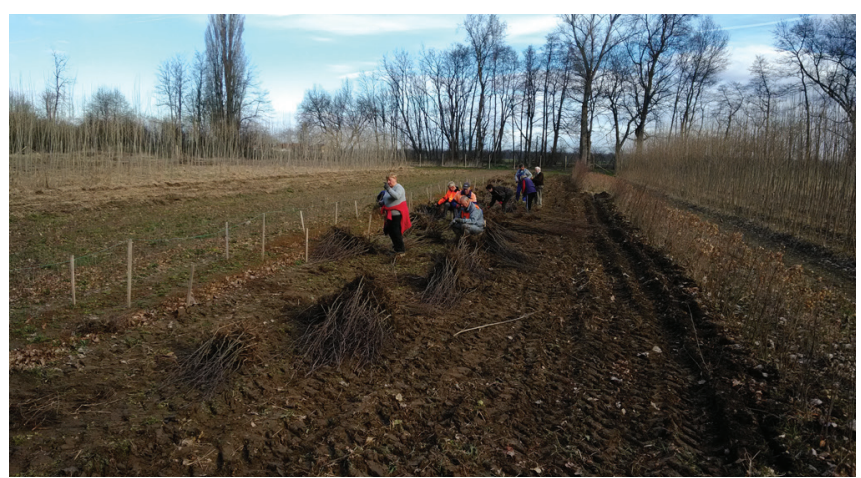

Excavation of seedlings of black alder prior their transport to the planting site (Photo: M. Černela) 
To prevent the seedlings from drying out, the following procedures should be followed:

- After excavation in a nursery, the seedlings should be transported to storage facilities as soon as possible. Seedlings should be stored in a cold and dark storage or in a refrigerator $\left(\right.$ at $+2{ }^{\circ} \mathrm{C}$ ). If seedlings are stored for more than a few days, it is necessary to moisten their roots. Seedlings should be stored until they are collected by a buyer.

- Seedlings should be transported to a planting site under tarpaulin protection or by refrigerated vehicles

- Before heeling in the seedlings, bundles of seedlings should be untied, and moist soil (not humus) spread over the roots. This allows contact between the roots and the soil. If there are many seedlings, trenches can be dug with a machine. Another method of storing seedlings at the planting site is under metalized reflective foil. Watering is necessary to maintain constant soil moisture, but seedlings should not be soaked in water or watered directly over the roots. Container seedlings cannot be heeled in. Therefore, transport must be organised to a designated storage for container seedlings near the planting site. The storage location can be outdoors but should not be in direct sunlight.

- The seedlings must be well protected from drying and mechanical damage during transport to the final planting site. When using container seedlings, it is advantageous to transport them in canvas bags or in special trays.

Good transport logistics and work organization ensure that seedlings remain in good condition until they are actually planted. The transport of bare-root seedlings and container seedlings does not differ much. However, transportation of container seedlings requires much more space. This is because containers cannot be stacked on top of each other and the seedlings are not bundled together. Sometimes special vans are used in which the containers are loaded on several levels, leaving enough vertical space for the above-ground parts of the seedlings in between. Since container trays are bulky and difficult to carry, special backpacks or hand carriers are used for multiple trays. For container seedlings, good road access is advisable due to the heavy tray weight. 


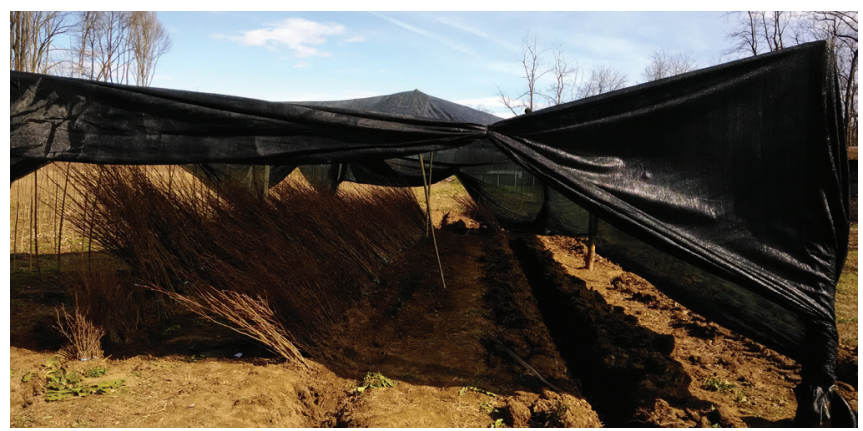

Protection of black alder seedlings from the spring sun at the planting site (Photo: M. Černela)

\subsection{Planting of seedlings}

Lately the winters have been getting drier and drier. This may diminish the success of a planting carried out in the autumn. If a dry winter is expected, it is advisable to soak the roots in water for a day or two before planting. If spring planting is planned, it must be done as close as possible to a predicted rainfall, but no more than 15 days before. Before planting, it is advisable to briefly immerse the roots of the seedlings in a muddy slurry. In general, it is still better to plant seedlings in the autumn, as dry springs are both more damaging and more common in most countries.

If seedlings are not planted immediately after delivery, special precautions must be taken to prevent drying out. For bare-root seedlings, cover the roots with soil to temporarily store them in the ground before planting. Container seedlings can be stored above ground away from direct sunlight and watered as needed.

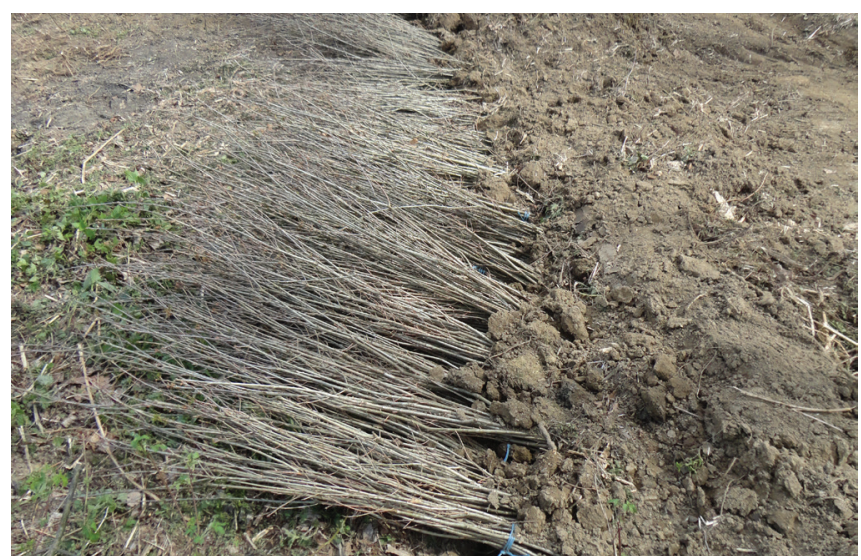

Bare-root seedlings are placed in trenches and covered with soil for temporary storage on the site before planting (Photo: G. Božič) 
In riparian forests, bare-root seedlings and wildlings of most riparian tree species (except poplars and willows) are planted manually. First, planting pits are excavated. The roots are then spread throughout the pit. Gradually, soil is added and the seedling is pushed in by hand. At the end, the soil around the seedling is lightly pressed with the foot so as not to destroy the roots of the seedlings, but hard enough so that a seedling cannot be pulled out with a gentle hand pull. Seedlings must be covered with soil up to the same height as they were in the nursery.

Container seedlings are planted using special planting tools called corers, which are usually provided by the seedling producers. Care should be taken when using these tools in clay soils or when the soil is too wet, otherwise the soil pores might get closed by the torsion of the tool and the plants will have trouble rooting. Before planting, ground vegetation should be adequately suppressed. The place where a hole is to be made for the container seedling must be completely cleared of ground vegetation. This greatly increases the survival rate of a seedling in the first year after planting. Plots with container seedlings require significantly more ground vegetation control in the first few years after planting due to smaller size of the seedlings compared to other seedling types. Container seedlings should be planted deep enough or they tend to succumb to drought stress. After a seedling is in the ground, gently press down on the substrate with the seedling using your hands. This allows the substrate to adhere to the soil.

Immediately after planting, bare root and container seedlings must be individually protected from browsing unless the planting area has been previously fenced. Mowing of competing vegetation is also advisable during the first two years. 


\section{Protocols for seedling production of main riparian tree species}

\subsection{Alnus glutinosa (L.) Gaertn., black alder}

\section{Seed collection}

Black alder trees growing in a stand begin fruiting at about age 30, whereas solitary trees begin fruiting at least 10 years earlier. Alders can produce seed every year, but abundant seed crops come every two to three years. Conelets with seeds are harvested from standing trees or recently felled trees when they are ripe. This is when their colour changes from black to brown, usually in October. From then on, the conelets can be collected until the end of the year.

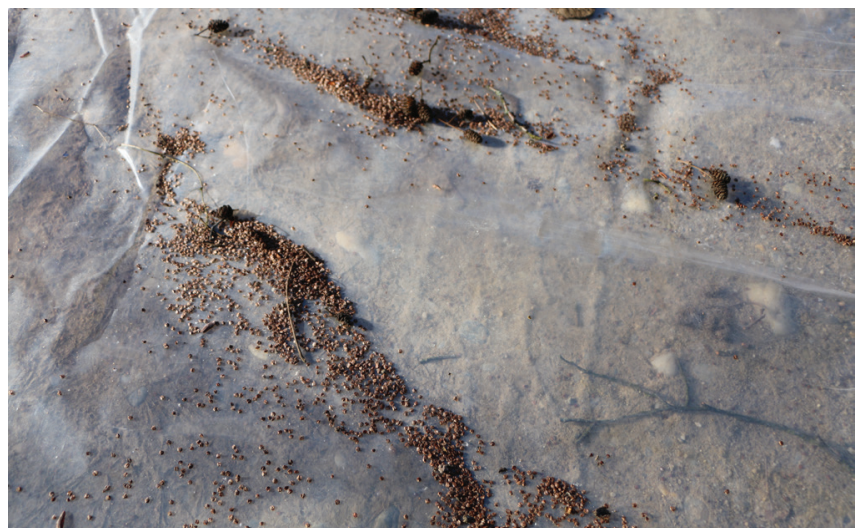

Black alder conelets and seeds are collected on a sheet after beating up three branches (Photo: M. Lanšćak)

About 15 to $20 \mathrm{~kg}$ of conelets are needed for $1 \mathrm{~kg}$ of seeds. As the conelets have a relatively high moisture content, they must be transported quickly to the nursery after harvesting. They open and release seeds when the moisture content drops to 8 or $9 \%$. 


\section{Seed storage and handling}

Dried black alder seeds can be stored in a refrigerator for up to five years. For details, please see table 3.

\section{Seedling handling in a nursery}

Seeds are sown densely on a seedbed in spring, during wet weather conditions. In Slovenia, this is most often done in mid-May.

Before sowing, the seeds are soaked in water for two to three days. Stratification of the seeds is not necessary.

The seedlings are watered if necessary, weeds are removed. Towards the end of June, the seedlings are fertilised with a mineral fertiliser.

After one year, in spring, the seedlings are transplanted using a transplanting machine which also prunes the root system to achieve a slightly bushier and denser root growth. The distance between the individual seedlings should be about $20 \mathrm{~cm}$.

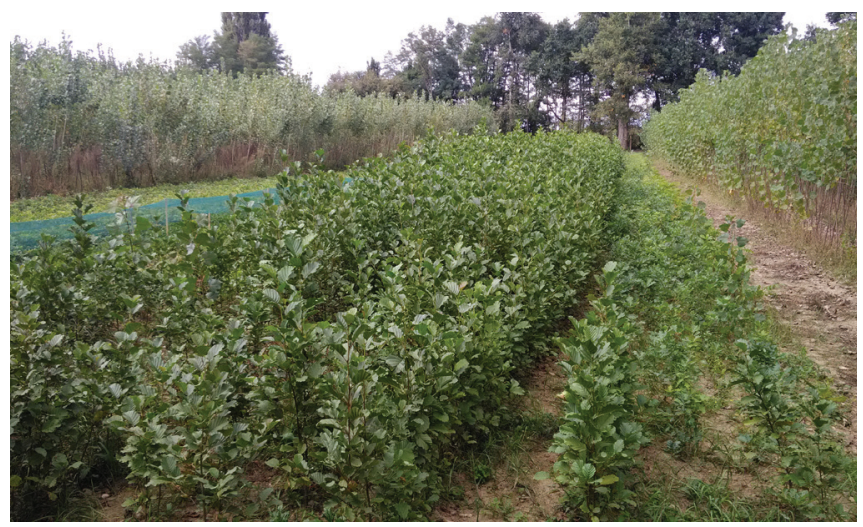

Production of black alder seedlings in a small-size forest nursery (Photo: M. Černela)

\section{Seedling handling while waiting for transport}

Black alder seedlings are very sensitive to drought. After they have been dug up in the nursery, they should be kept in bundles, covered with moist soil, awaiting transportation.

\subsubsection{Production of black alder seedlings using hydroponic technology}

The production of black alder seedlings has a long tradition in the nursery Limbuš of Hrvatske šume d.o.o. Since 2006, ecological hydroponic technology has been used for this purpose. In hydroponic cultivation, plants develop on the water surface and their roots develop within a nutrient solution. 


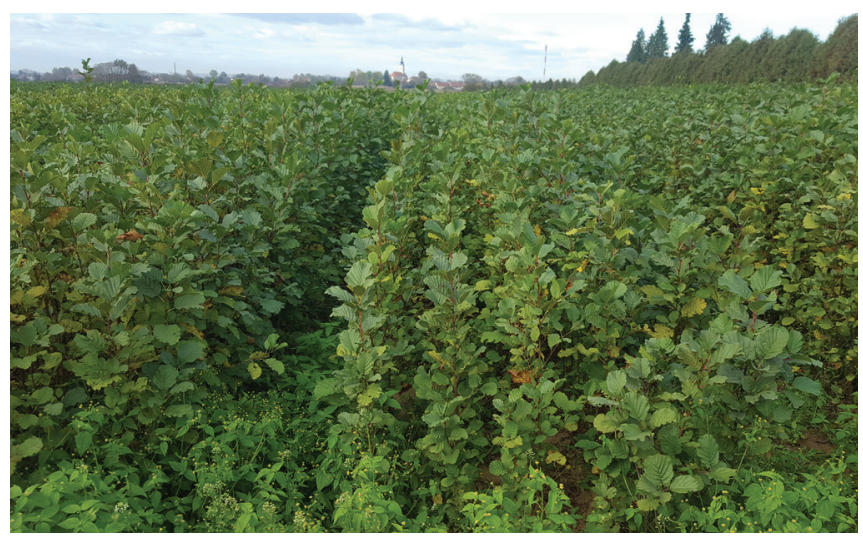

Transplanted black alder seedlings in seedbeds in five rows per bed (Photo: M. Lanšćak)

No pesticides are used in hydroponics, so cultivation causes no environmental pollution. Other advantages include a lower incidence of pathogens, a high degree of automation, high production intensity, less work in processing and disinfection, and lower consumption of water and nutrients. 


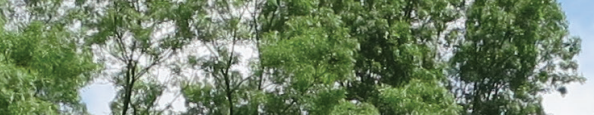

int 198.

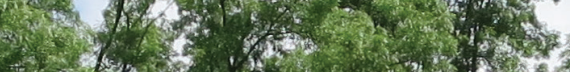

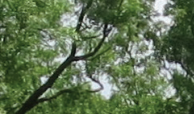

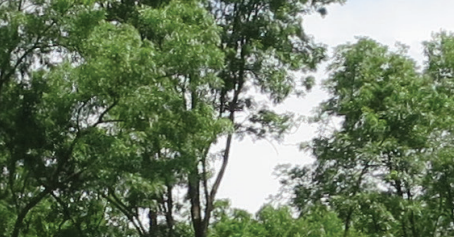
s.

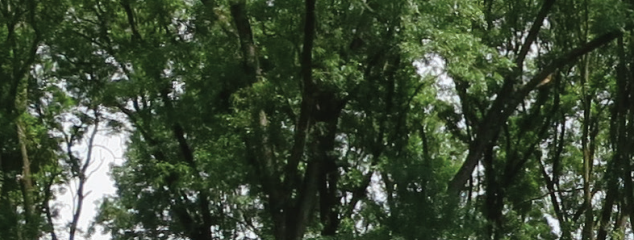

(1) 1. 3 (2) is

$-1,2$

3.th

ghis

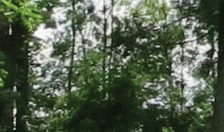

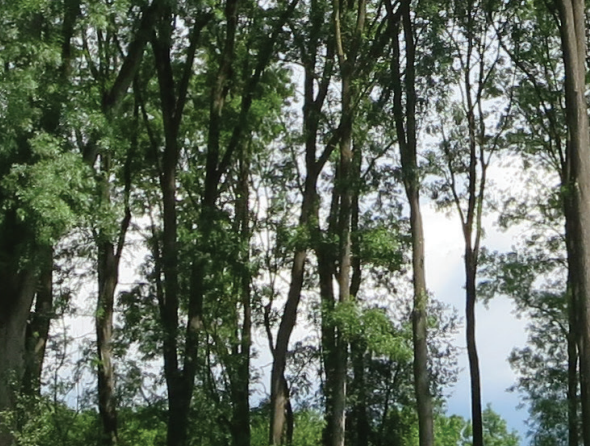

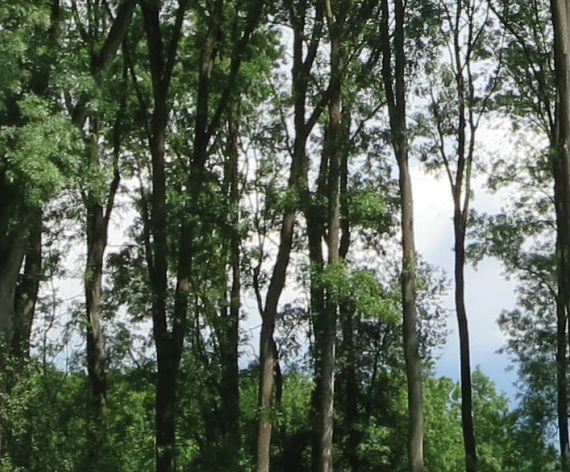

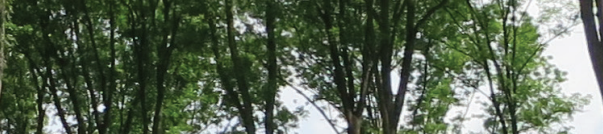
(1)

1.

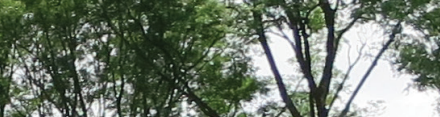
(2). 


\subsection{Fraxinus angustifolia Vahl. and Fraxinus excelsior L., narrow-leaved and common ash}

\section{Seed collection}

Seed is collected either in August, September, or October while it is still green. Depending on the time of seed collection, seed handling differs.

\section{Seed storage and handling}

If the seed is collected in (early) August, stratification in wet sand and storage at $2{ }^{\circ} \mathrm{C}$ follows. Sowing is done in spring, after late frosts.

When the seed is harvested in September (or when the seed stalks begin to turn brown), stratification of the seed follows for two to three months at 12 to $15^{\circ} \mathrm{C}$. After two to three months, the seed is stored at $0{ }^{\circ} \mathrm{C}$ for the rest of the time until sowing in April.

When the seed is harvested in October, it is immediately sown densely by hand in seedbeds and covered with a thin layer of soil.

\section{Seedling handling in a nursery}

During the first growing season, the seedbed is weeded and watered regularly. Occasionally, nutrient supplements are administered for leaf development. In addition, plant protection is applied as needed during the growing season to protect seedlings from harmful insects and diseases. Insecticides such as Actara or Mospilan and fungicides such as Sphere SC, Signum or copper oxychloride are used. Against infection by Hymenoscyphus albidus (ash dieback), seedlings should be sprayed every three weeks with Sphere SC or Signum, as is the practise in Austria. However, copper may only be applied in quantities of less than $28 \mathrm{~kg}$ per hectare over a period of seven years.

After the first year, plants are removed from a seedbed and transplanted into tilled soil with a spacing of $0.80 \mathrm{~m} \times 0.25 \mathrm{~m}$ between each plant. After transplanting, during the second growing season, hoeing, weeding and watering is done. Fertilisers are also administered several times during the growing season to increase leaf growth. In addition, the same pesticides are applied in the second growing season as in the first growing season. At the end of the second year, the seedling type is $1+1$. For older seedlings, such as $1+2$, the roots are pruned (undercut) with a plough in the spring of the third year, and immediately after pruning, the plants are watered and the soil around them is tamped down. 


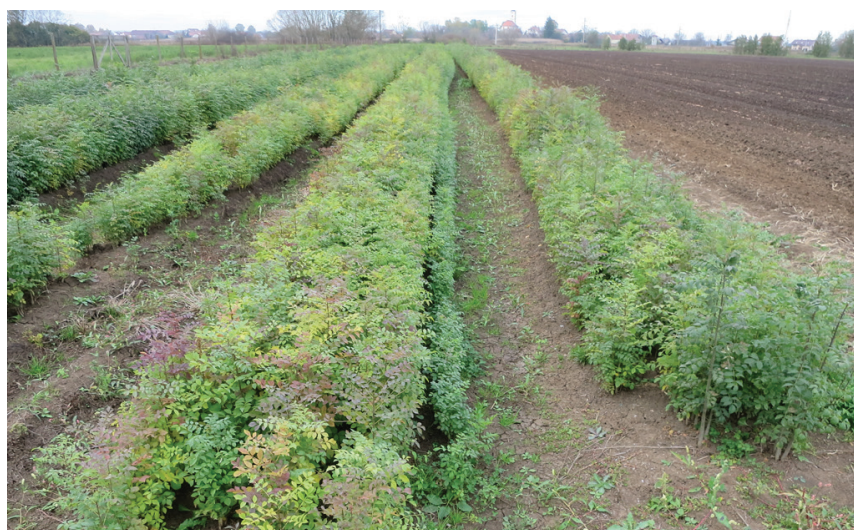

Narrow-leaved ash in forest nursery Limbuš, Croatia (Photo: G. Božič)

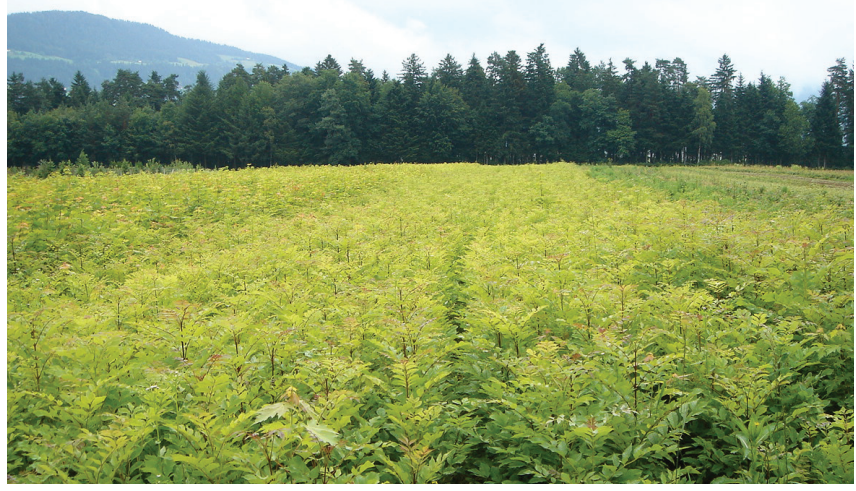

Common ash in nursery Omorika, Slovenia (Photo: M. Herman - Planinšek)

\section{Seedling handling while waiting for transport}

Standard measures described in the previous chapters are used to prevent seedlings from drying out. 


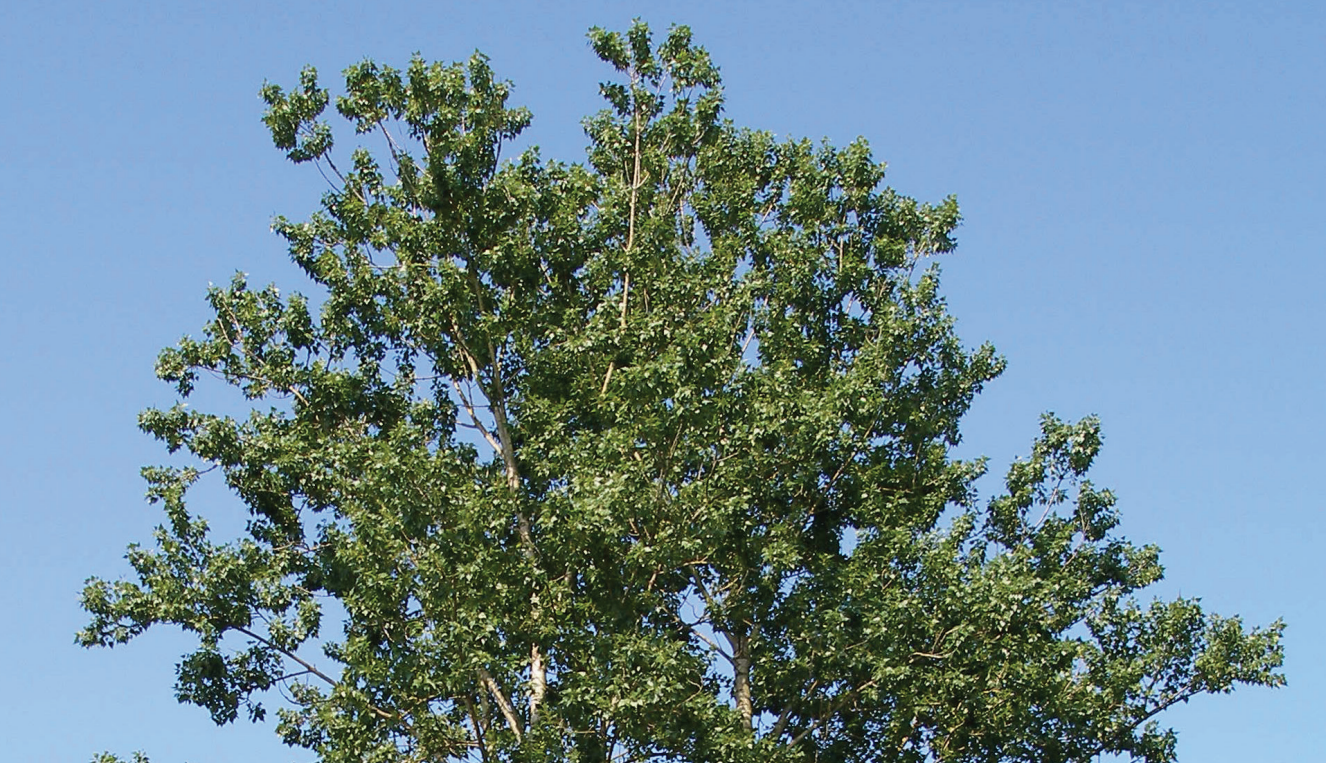

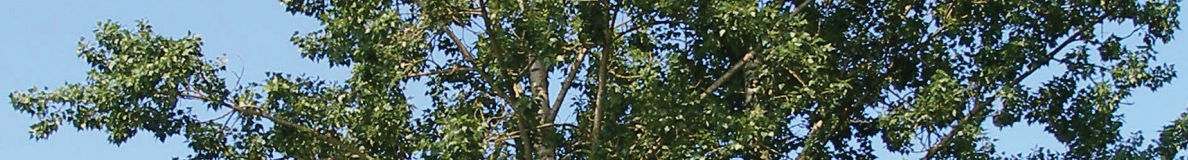

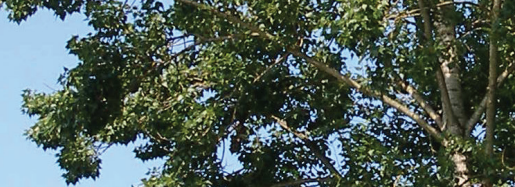

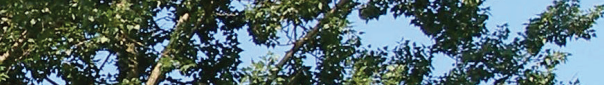

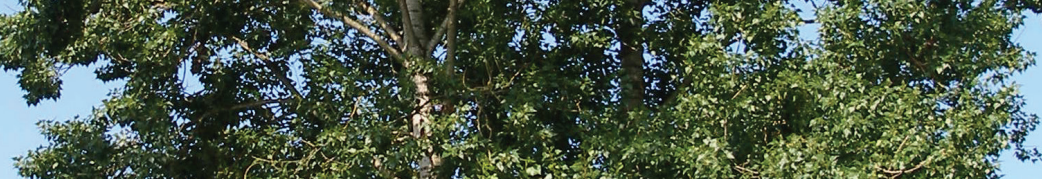
t. the -

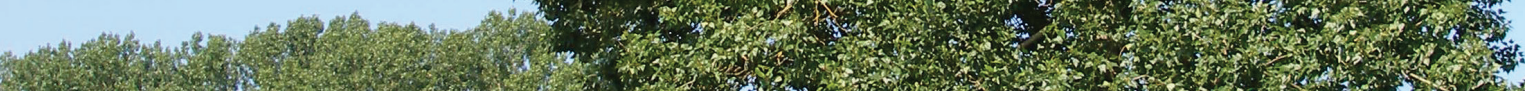

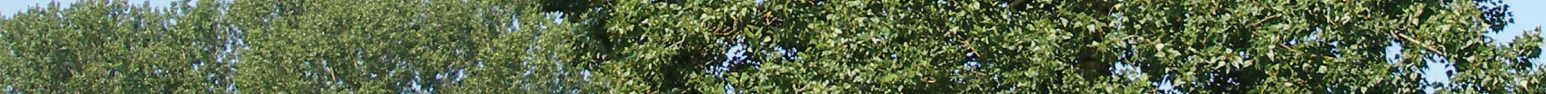

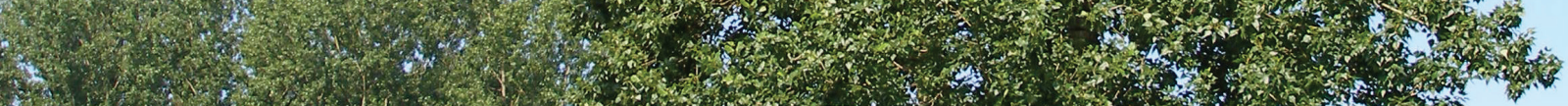

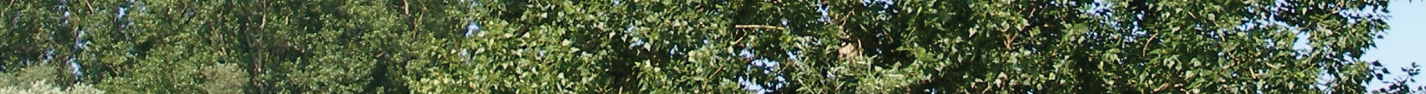

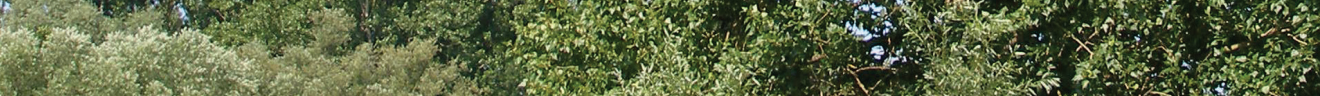
2.

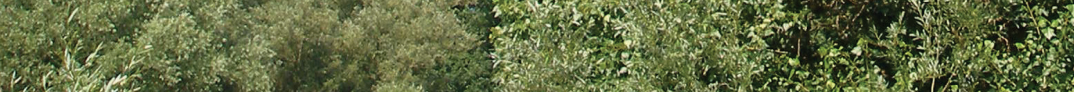

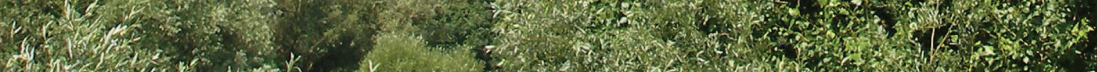

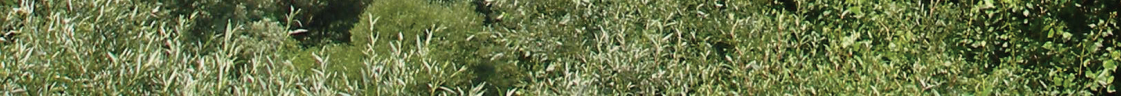

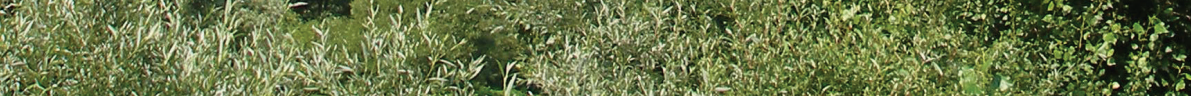

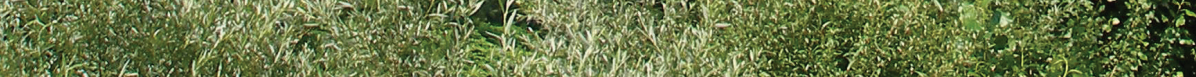

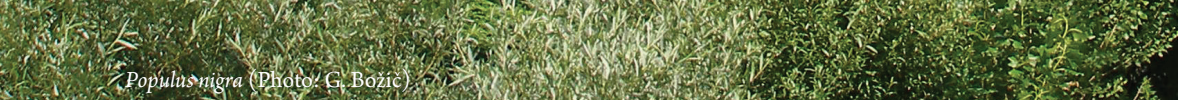
-

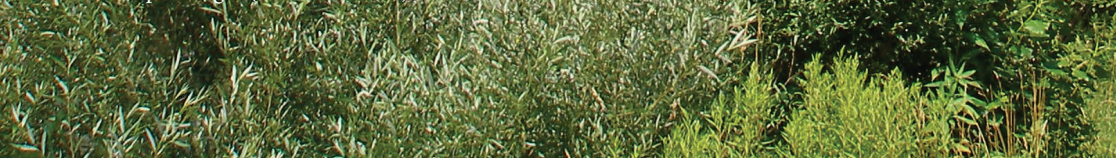
s.

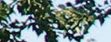

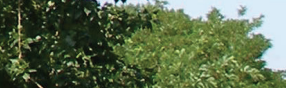




\subsection{Populus nigra L., European black poplar}

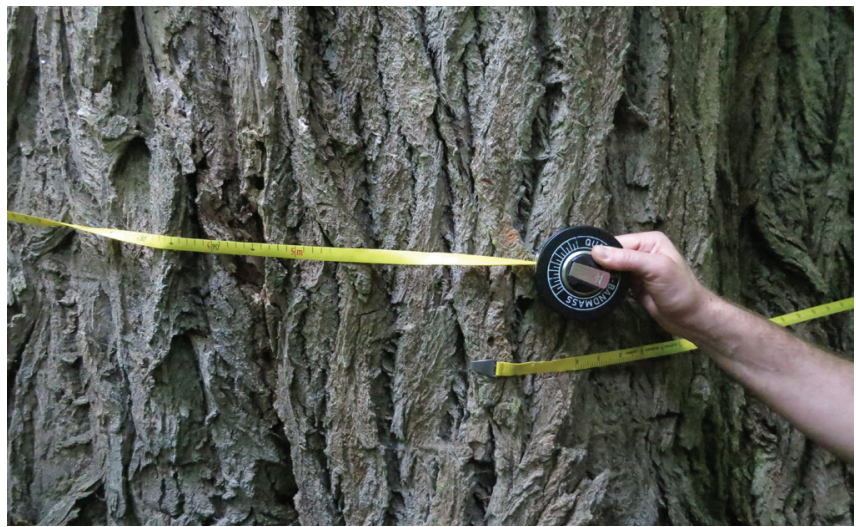

Autochthonous European black poplar trees can reach massive dimensions in the

Mura-Drava-Danube Biosphere Reserve (Photo: G. Božič)

\section{Cuttings production}

Autochthonous European black poplar trees are identified on the basis of morphometric characteristics using the EUFORGEN identification key for black poplar (see literature used).

Among the trees identified in the previous step, those with at least one well-developed one-year-old upright shoot with dormant buds growing from the trunk at reachable height or at the base of the trunk are further selected.

A suitable one-year-old shoot measures at least $1 \mathrm{~cm}$ in diameter at the shoot base.

Cuttings that come from large, old trees usually have the least possibility of rooting. Rooting of cuttings is also genetically determined. Cuttings that have the highest probability of rooting come from:

- $\quad$ one-year-old upright shoots growing from the main branches of young adult black poplars that still have a large height increment (i.e., younger than about 12 years),

- $\quad$ one- or two-year-old upright shoots on pollarded trees, and

- one-year-old upright shoots from vital capped snags.

In a nursery, the most vital shoots are produced by cuttings from one-year-old poplar seedlings. These are therefore the most suitable for producing forest reproductive material in registered rootstocks of poplar clones.

Garden shears or shears on a telescopic handle are used to remove one-year-old shoots (switches) from trees to produce cuttings. 
Switches/shoots are cut at the end of winter in dry weather when vegetation is dormant. The lowest part and thinnest upper part (non-woody tip) of a switch/shoot are not suitable for cuttings production and must be discarded. The rest of the shoot is cut into cuttings. The cuttings should be 18 to $40 \mathrm{~cm}$ long and 8 to $13 \mathrm{~mm}$ in diameter. The upper cut is made with sharp scissors horizontally just above a dormant bud and the lower one diagonally below a dormant bud. This way, the two ends of the cuttings can still be easily distinguished after cutting. Sharp scissors are required to avoid damaging the bark of the cutting. There must be at least three to four buds on each cutting, of which the upper one (the horizontal one directly above a dormant bud) must be well developed and undamaged.

Cuttings that come from the same mother tree are placed in a bundle. The thicker parts of each cutting are always stacked together. The bundle is labelled with an identification number linking a bundle to the parent tree.

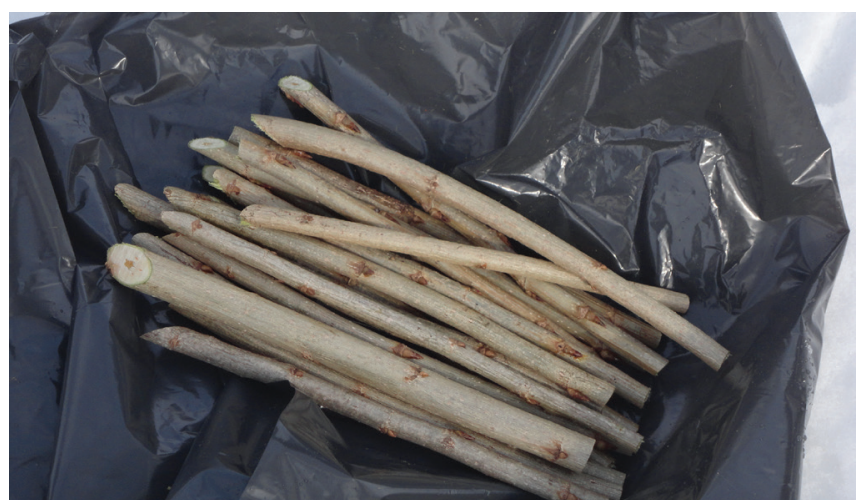

Cuttings of a single black poplar genotype before they are tied into a bundle (Photo: G. Božič)

Production of poplar cuttings and seedlings has to be supervised by the authorized institutions. Disinfection of cuttings and seedlings is mandatory.

\section{Cuttings storage and handling}

Cuttings are stored in a refrigerator at $4{ }^{\circ} \mathrm{C}$ to inhibit bud growth until planting. The bundles of cuttings should be wrapped in paper. The paper should be kept moist but not soaked to prevent the growth of undesirable fungi. Regular inspection of the stored material is advisable. 


\section{Cuttings handling in a nursery}

Cuttings are planted in prepared beds in early spring (late March or early April). Light, rock-free soil with a $\mathrm{pH}$ of 5.5 to 7.5 is best. Dry, sandy soils and soils exposed to wind are not suitable for growing poplars from cuttings. The soil in a nursery should be prepared in autumn by ploughing it at least $40 \mathrm{~cm}$ deep. Before planting cuttings, it is necessary to clear the surface, remove the existing vegetation, finely prepare and disinfect the soil.

It is recommended to soak the lower end of the cuttings in water for 24 hours immediately before planting.

Cuttings are planted vertically deep enough into the soil so that only the top bud is visible a few $\mathrm{cm}$ above the soil surface. The soil around a planted cutting is pressed well with the feet. When planting, the top bud and bark must remain undamaged. Care must also be taken to prevent the cuttings from drying out in the sun or wind. The cuttings are then covered with a thin layer of light soil. Regular weeding, hoeing and watering should be done.

The planting area must be marked. Each genotype of poplar (clone) must be planted in a separate area. Records of the number of cuttings planted, survival rate and growth performance of each clone must be kept at the facility.

\section{Young plants of rooted cuttings (i.e. seedlings) handling in a nursery}

Weeding and releasing seedlings from competition should be done regularly, seedlings should be hoed several times. Weeds greatly hinder the development of seedlings. The side branches of seedlings should not be cut. If two tops appear, the worse one is cut off.

At the end of winter, one or two-year-old seedlings are cut off $5 \mathrm{~cm}$ above the ground and new cuttings are produced for the propagation of the genotype. In a nursery, they are planted in rows, spaced about 30 to $40 \mathrm{~cm}$ apart within a row and 50 to 70 $\mathrm{cm}$ between rows. A higher planting density produces slender and weak seedlings that tend to bend and resist the wind poorly after being transplanted into the field.

The herbaceous layer in the first and second year of growth should not exceed the size of shoots or seedlings. It should be removed next to the seedlings to prevent rodents from damaging the seedlings in winter. Appropriate herbicides can also be used to control the herbaceous layer. Protection against defoliators may be required after leaf emergence. 
The facility must be fenced with a strong fence to protect the seedlings from herbivores.

\section{Seedling handling while waiting for transport}

When poplar seedlings are dug up, the root part should be heavily covered with moist soil. Seedlings should also be covered with a shading net to make them less susceptible to drying out.

Type $1+2$ or $2+3$ seedlings are used for planting. 


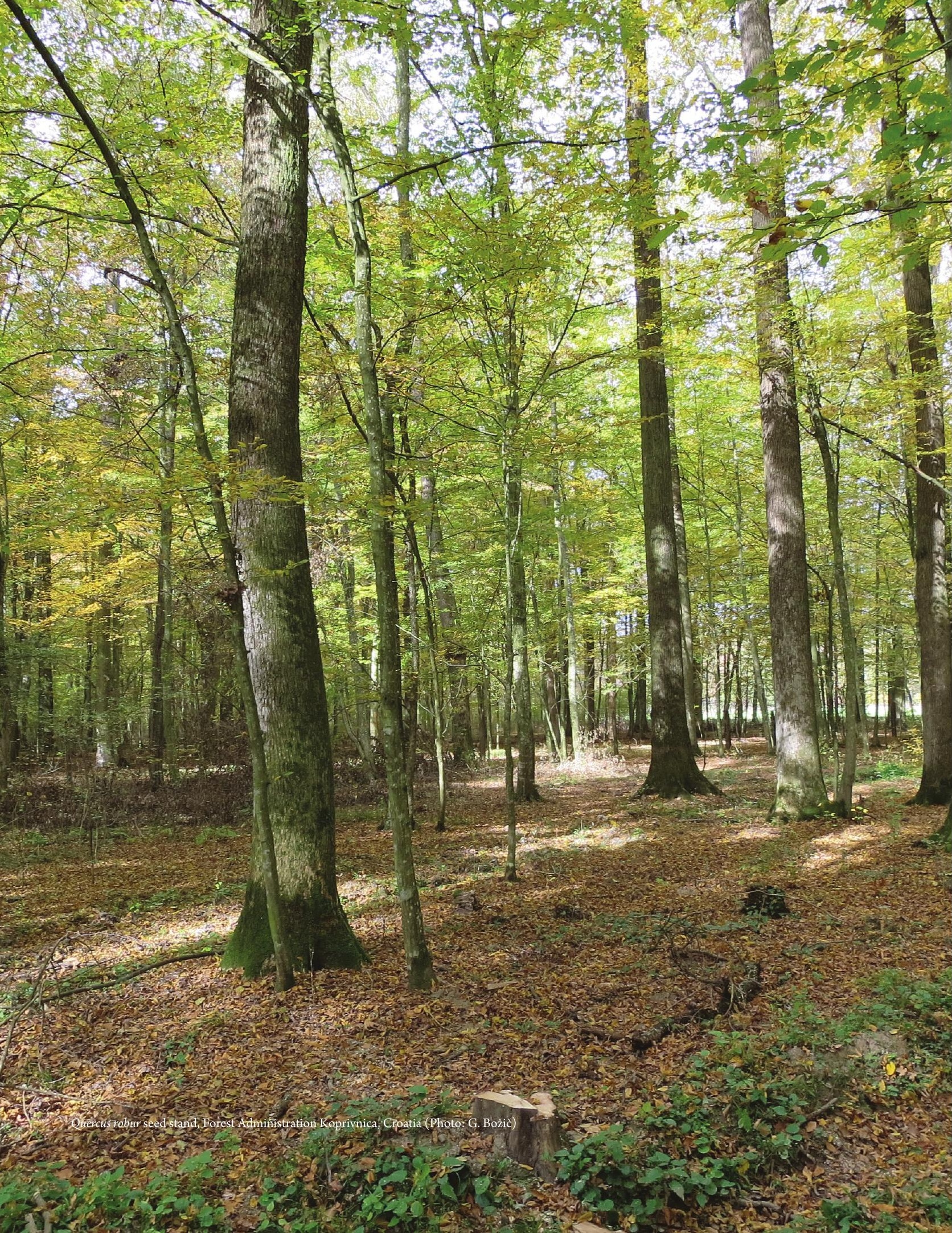




\subsection{Quercus robur L., pedunculate oak}

\section{Seed collection}

Acorns are harvested in the fall, usually in October, depending on ripeness. Damaged acorns and acorns with holes are sometimes discarded. This last step is often neglected because it requires a lot of manual labour. This can also have a positive effect, as damaged acorns can still produce seedlings if the embryo is intact.

\section{Seed storage and handling}

Seeds are stored for a relatively short time and sown as soon as possible, usually in October or November. In Croatia, the seeds are sown by hand in straight rows 2 to $5 \mathrm{~cm}$ deep in narrow seedbeds and covered with a thin layer of soil.

In Slovenia the acorns are treated with a substance that repels rodents, while in Serbia no additional treatment is used.

It is important to take the acorns from the forest to a storage facility and then plant them as quickly as possible, preferably immediately after bringing them to a nursery.

Floating the acorns in $40^{\circ} \mathrm{C}$ water for three hours and then drying and storing them at about $-3{ }^{\circ} \mathrm{C}$ is practised in Austria to allow sowing in spring and thus avoid damage by rodents during the winter.

\section{Seedling handling in a nursery}

Sowing is done manually as in Slovenia or with machines in rows previously prepared with special machines.

In Slovenia the acorns sown are covered with sawdust from conifers, but not thicker than twice the thickness of the acorns. This is because the seedlings grow more easily through the sawdust than through the soil.

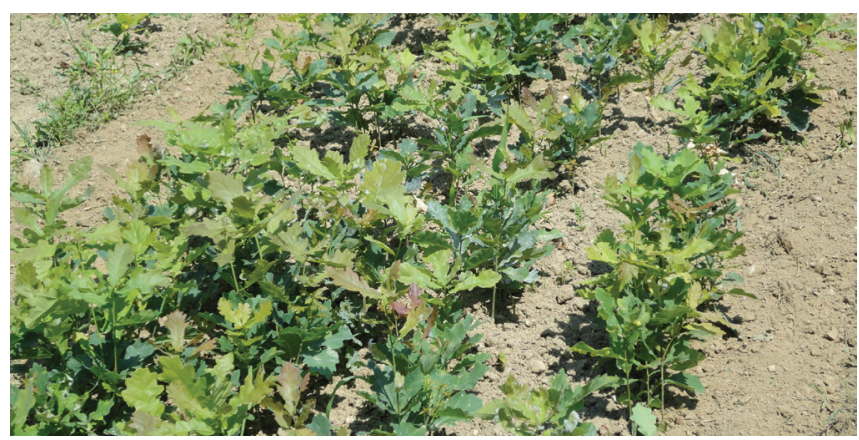

Seedlings of oak during the first growing season in nursery Omorika, Slovenia (Photo: M. Herman - Planinšek)

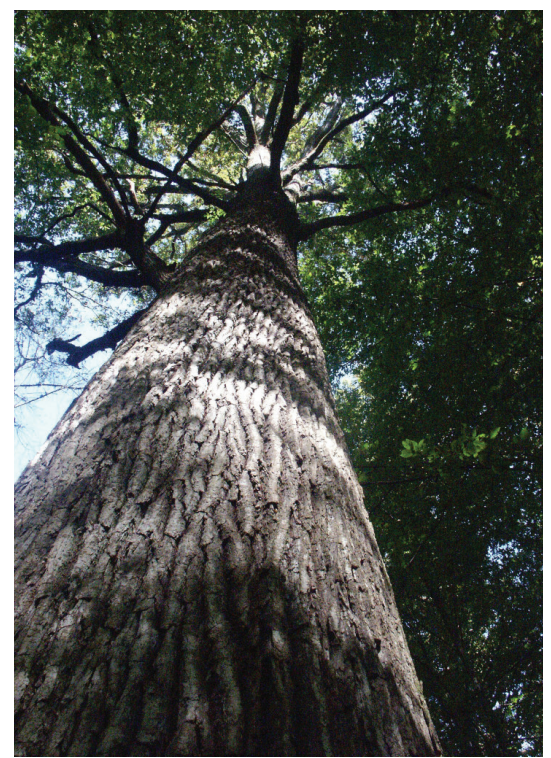

Quercus robur (Photo: S. Bogdan) 
After the first year, the plants are removed from the seedbed and transplanted to a growing site in milled soil with a distance of 0.80 $\mathrm{m} \times 0.25 \mathrm{~m}$ between each plant. In Slovenia, the distance between seedlings is smaller, only about $20 \mathrm{~cm}$.

After transplanting, during the second growing season, hoeing, weeding and watering is done as needed. Mineral supplements to increase leaf growth are also given several times during the growing season.

In the second year (and all subsequent years if such material is grown), the roots are pruned with a plough in the spring to establish a quality root system.

Seedling production usually takes three $(1+2)$ years, producing seedlings about $80 \mathrm{~cm}$ tall (although they can grow to over $1 \mathrm{~m}$ tall) with a well-developed root system.

Throughout the production process, protection against oak powdery mildew (Erysiphe alphitoides), oak lace bug (Corythucha arcuata) and oak flea beetle (Haltica quercetorum) is carried out in the countries where they occur. It is best to rotate pesticides and fungicides to avoid resistance. Pesticides based on bifentrin (Bifenicus) and thiamethoxam (Actara, Amos, Cruiser 70 WS) have shown excellent efficacy against oak lace bug in Serbia. Against powdery mildew, mainly sulphur-based fungicides are used.

\section{Seedling handling while waiting for transport}

Oak seedlings are bundled and put back in the ground immediately after digging them out and covered with soil. Water is poured over the roots. In this way, the roots are only minimally exposed to external drought influences.

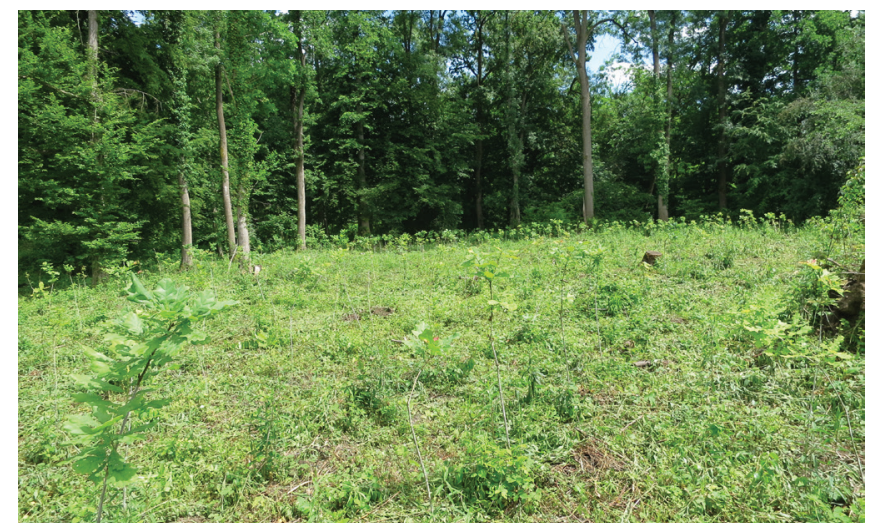

Artificial regeneration of pedunculate oak (Photo: G. Božič) 


\subsection{Ulmus laevis Pall. and Ulmus minor Mill., European white elm and field elm}

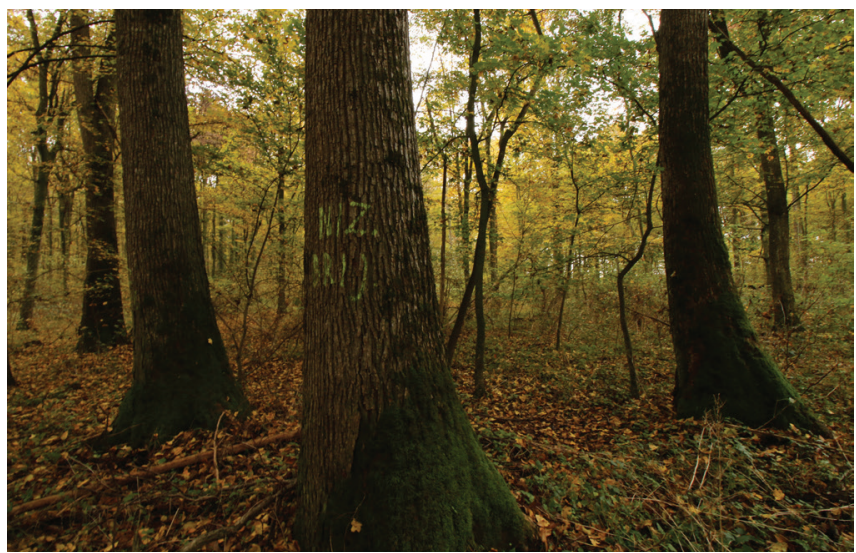

Ulmus minor along the Drava river in Croatia (Photo: M. Lanšćak)

\section{Seed collection}

Seed is collected in the first half of May.

\section{Seed storage and handling}

Fresh seeds are sown immediately after harvest in May. They are sown densely by hand in seedbeds and covered with a thin layer of soil. Another option used in Austria is sowing in spring after stratification.

\section{Seedling handling in a nursery}

During the following growing season, the seedbed is weeded and watered regularly, and supplements are occasionally given for leaf development. In addition, plant protection is applied as needed during the growing season to protect the seedlings from harmful insects and diseases. Insecticides such as Actara or Mospilan and fungicides such as Sphere SC, Signum or copper oxychloride are used. However, copper may only be applied at rates of less than 28 $\mathrm{kg}$ of copper per hectare over a 7-year period.

After the first year, plants are removed from a seedbed and transplanted into tilled soil with $0.80 \mathrm{~m} \times 0.25 \mathrm{~m}$ spacing between each plant. After transplanting, during the second growing season, hoeing, weeding and watering are done. Fertilisers are also administered several times during the growing season to increase leaf growth. In addition, the same pesticides are applied in the second growing season as in the first growing season. At the end 
of the second year, the seedling type is $1+1$. For older seedlings, such as $1+2$, the roots are pruned with a plough in the spring of the third year, and immediately after pruning, the plants are watered and the soil around them is trampled.

\section{Seedling handling while waiting for transport}

The same protocol is used as for oak.

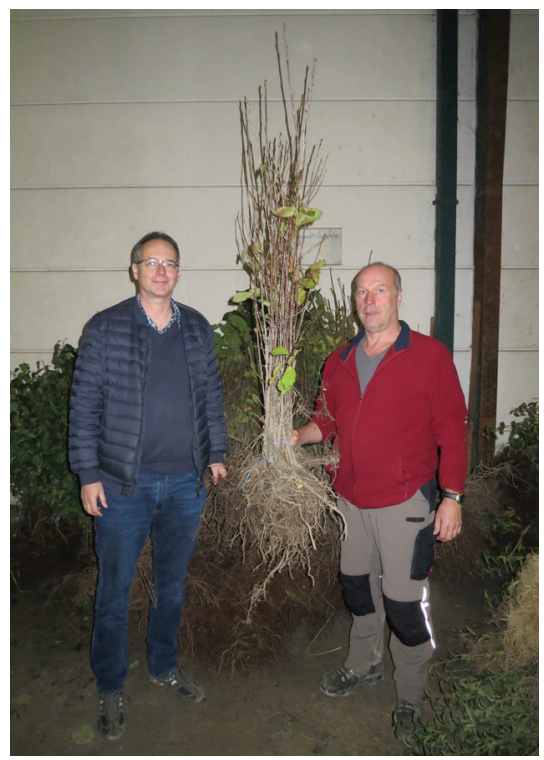

Elm seedlings in the Schwanzer forest tree nursery storage facility (Photo: S. Schüler) 


\section{List of forest nurseries producing forest reproductive material for riparian forests of the Mura-Drava-Danube Biosphere Reserve}

\begin{tabular}{|c|c|c|c|c|c|c|c|}
\hline 를 & Name and address & Contact information & $\begin{array}{l}\text { Lat., } \\
\text { Long. }\end{array}$ & $\stackrel{巳}{E}$ & $\underset{\frac{g}{g}}{\stackrel{g}{g}}$ & दे & 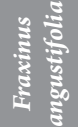 \\
\hline \multirow{4}{*}{$\frac{\mathfrak{m}}{\overline{0}}$} & $\begin{array}{l}\text { Gozdarstvo Turnišče d.o.o., } \\
\text { Ulica Štefana Kovača 6, SI-9224 } \\
\text { Turnišče }\end{array}$ & $\begin{array}{l}\text { mitja.cernela(at)gmail.com } \\
+386(0) 40334142\end{array}$ & $\begin{array}{l}46.5876 \\
16.2038\end{array}$ & 179 & 2.8 & $\mathrm{X}$ & \\
\hline & $\begin{array}{l}\text { Trgovina z lesom, Franc Kreft } \\
\text { s.p., Kutinci 5, SI-9244 Sveti Jurij } \\
\text { ob Ščavnici }\end{array}$ & $\begin{array}{l}\text { kreft.franci(at)gmail.com } \\
+386 \text { (0) } 40334142\end{array}$ & $\begin{array}{l}46.5508 \\
15.9753\end{array}$ & 271 & 0.42 & & \\
\hline & $\begin{array}{l}\text { Forest nursery Omorika, } \\
\text { Koroška street 44, SI-2366 Muta }\end{array}$ & $\begin{array}{l}\text { https://www.omorika.si/ } \\
\text { drevesnica(at)omorika.si } \\
\text { +386(0)31621 643 } \\
\text { +386(0)41621643 } \\
\text { +386 (0)2 } 8769000 \\
\text { +386(0)2 } 8761319\end{array}$ & $\begin{array}{l}46.6000 \\
15.1527\end{array}$ & 380 & 15 & $\mathrm{X}$ & \\
\hline & $\begin{array}{l}\text { BLS GOZD d.o.o and ARBORIS } \\
\text { Janez Kolenko s.p., Polanska } \\
\text { ulica 40, Kapca, SI-9220 } \\
\text { Lendava }\end{array}$ & $\begin{array}{l}\text { kolenko.j(at)gmail.com } \\
+386(0) 41657843\end{array}$ & $\begin{array}{l}46.5910 \\
16.3638\end{array}$ & 165 & 0.6 & $\mathrm{X}$ & \\
\hline \multirow{5}{*}{ 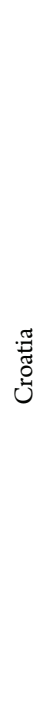 } & $\begin{array}{l}\text { Nursery Limbuš, Pridvorje bb, } \\
48362 \text { Kloštar Podravski }\end{array}$ & $\begin{array}{l}\text { www.hrsume.hr } \\
\text { sonja.rukavina(at)hrsume.hr } \\
\text { www.hrsume.hr } \\
\text { +385(098) } 451521\end{array}$ & $\begin{array}{l}45.9894 \\
17.1709\end{array}$ & 115 & 15.3 & $\mathrm{X}$ & $\mathrm{X}$ \\
\hline & $\begin{array}{l}\text { Nursery Drnje, Kolodvorska bb, } \\
48322 \text { Torčec }\end{array}$ & $\begin{array}{l}\text { www.hrsume.hr } \\
\text { sonja.rukavina(at)hrsume.hr } \\
\text { www.hrsume.hr } \\
\text { +385 (098) } 451521\end{array}$ & $\begin{array}{l}46.2137 \\
16.8918\end{array}$ & 128 & 12.19 & & $\mathrm{X}$ \\
\hline & $\begin{array}{l}\text { Nursery Močile, Močile 12, } \\
48000 \text { Koprivnica }\end{array}$ & $\begin{array}{l}\text { www.hrsume.hr } \\
\text { sonja.rukavina(at)hrsume.hr } \\
\text { www.hrsume.hr } \\
\text { +385(098) } 451521\end{array}$ & $\begin{array}{l}46.1787 \\
16.7839\end{array}$ & 149 & 11.22 & & \\
\hline & $\begin{array}{l}\text { Nursery Zelendvor, Ulica } \\
\text { grofa Bombellesa 4/d, } 42206 \\
\text { Petrijanec }\end{array}$ & $\begin{array}{l}\text { www.hrsume.hr } \\
\text { sonja.rukavina(at)hrsume.hr } \\
\text { www.hrsume.hr } \\
+385 \text { (098) } 451521\end{array}$ & $\begin{array}{l}46.3346 \\
16.2014\end{array}$ & 166 & 21.65 & & \\
\hline & $\begin{array}{l}\text { Nursery Višnjevac, Lugarski put } \\
1,31220 \text { Višnjevac }\end{array}$ & $\begin{array}{l}\text { www.hrsume.hr } \\
\text { Helena.Prevoznik(at)hrsume.hr } \\
\text { +385 (098) } 447066\end{array}$ & $\begin{array}{l}45.5727 \\
18.6134\end{array}$ & 90 & 26.16 & & $\mathrm{X}$ \\
\hline
\end{tabular}




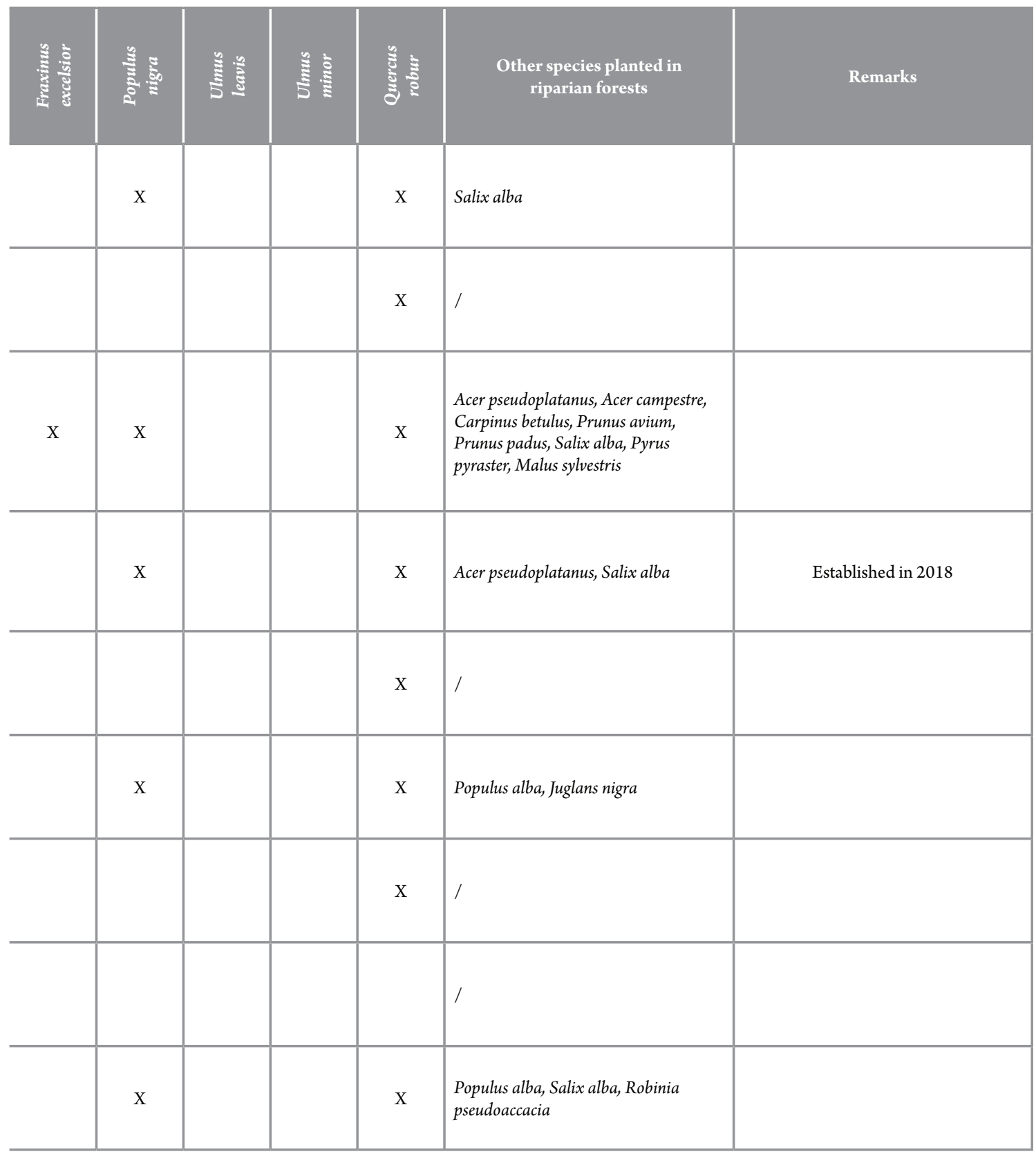




\begin{tabular}{|c|c|c|c|c|c|c|c|}
\hline 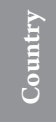 & Name and address & Contact information & $\begin{array}{l}\text { Lat., } \\
\text { Long. }\end{array}$ & 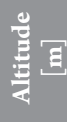 & $\frac{\text { g }}{\frac{g}{8}}$ & $\frac{\tilde{z}}{3}$ & 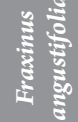 \\
\hline \multirow{5}{*}{ 竭 } & $\begin{array}{l}\text { University of Novi Sad, Institute } \\
\text { of Lowland Forestry and } \\
\text { Environment, Antona Čehova } \\
\text { 13, Novi Sad }\end{array}$ & $\begin{array}{l}\text { www.ilfe.org } \\
\text { ilfe(at)uns.ac.rs } \\
+38121540383\end{array}$ & $\begin{array}{l}45.2946 \\
19.8904\end{array}$ & 84 & 0.5 & & $\mathrm{X}$ \\
\hline & $\begin{array}{l}\text { Public Enterprise } \\
\text { "Vojvodinašume”, Forest Estate } \\
\text { "Banat", Maksima Gorkog 24, } \\
26000 \text { Pančevo }\end{array}$ & $\begin{array}{l}\text { www.vojvodinasume.rs/en } \\
\text { sdabic(at)vojvodinasume.rs } \\
\text { +38121431 } 144\end{array}$ & $\begin{array}{l}44.7305 \\
20.9891\end{array}$ & 68 & 18 & & \\
\hline & $\begin{array}{l}\text { Public Enterprise } \\
\text { "Vojvodinašume", Forest Estate } \\
\text { "Sombor", Apatinski put 11, } \\
25000 \text { Sombor }\end{array}$ & $\begin{array}{l}\text { www.vojvodinasume.rs/en } \\
\text { sdabic(at)vojvodinasume.rs } \\
\text { +38121431 } 145\end{array}$ & $\begin{array}{l}45.7807 \\
18.9196\end{array}$ & 101 & 21.5 & & $\mathrm{X}$ \\
\hline & $\begin{array}{l}\text { Public Enterprise } \\
\text { "Vojvodinašume", Forest } \\
\text { Estate "Sremska Mitrovica", } \\
\text { Parobrodska 2, } 22000 \text { Sremska } \\
\text { Mitrovica }\end{array}$ & $\begin{array}{l}\text { www.vojvodinasume.rs/en } \\
\text { sdabic(at)vojvodinasume.rs } \\
\text { +38121431 } 146\end{array}$ & $\begin{array}{l}45.0224 \\
19.2234\end{array}$ & 77 & 1.2 & & $\mathrm{X}$ \\
\hline & $\begin{array}{l}\text { Forest nursery “Vikumak", Vuka } \\
\text { Karadžića 9, } 23323 \text { Iđoš }\end{array}$ & $\begin{array}{l}\text { http://vikumak.co.rs } \\
\text { rasadnikvikumak(at)gmail.com } \\
\text { +381 } 23065265\end{array}$ & $\begin{array}{l}45.8237 \\
20.3321\end{array}$ & 76 & 8 & & \\
\hline \multirow{4}{*}{$\begin{array}{l}\hat{c} \\
\text { 总 } \\
\text { 至 }\end{array}$} & $\begin{array}{l}\text { Forestry nursery 'Beck Antal', } \\
\text { Deák F. u. 8/a., } 7756 \text { Borjád, }\end{array}$ & $\begin{array}{l}+3669372010 \\
\text { antal.beck(at)gmail.com, info(at) } \\
\text { beckcsk.hu } \\
\text { http://www.beckcsk.hu }\end{array}$ & $\begin{array}{l}45.9354 \\
18.4664\end{array}$ & 110 & & $\mathrm{X}$ & $\mathrm{X}$ \\
\hline & $\begin{array}{l}\text { Ásványráró Nursery, } \\
\text { Rákóczi u. 6., } 9177 \text { Ásványráró }\end{array}$ & $\begin{array}{l}\text { +36 } 96716844 \\
\text { beliferenc(at)hotmail.com }\end{array}$ & $\begin{array}{l}47.8341 \\
17.5087\end{array}$ & 108 & 17 & & \\
\hline & $\begin{array}{l}\text { Tolna Nursery, Gemenc } \\
\text { Forestry, Plt. Szent Imre tér } 2 . \\
6500 \text { Baja }\end{array}$ & $\begin{array}{l}+36 \text { 79324-144 } \\
\text { gemenc(at)gemenczrt.hu } \\
\text { http://gemenczrt.hu }\end{array}$ & $\begin{array}{l}46.4216 \\
18.7977\end{array}$ & 95 & 28 & & \\
\hline & $\begin{array}{l}\text { Bajti Nursery, Forest Research } \\
\text { Institute, } \\
\text { Várkerület 30/a, } 9600 \text { Sárvár }\end{array}$ & $\begin{array}{l}\text { +3695320070 } \\
\text { erti@erti.hu }\end{array}$ & $\begin{array}{l}47.2698 \\
16.9770\end{array}$ & 160 & 65 & & \\
\hline
\end{tabular}




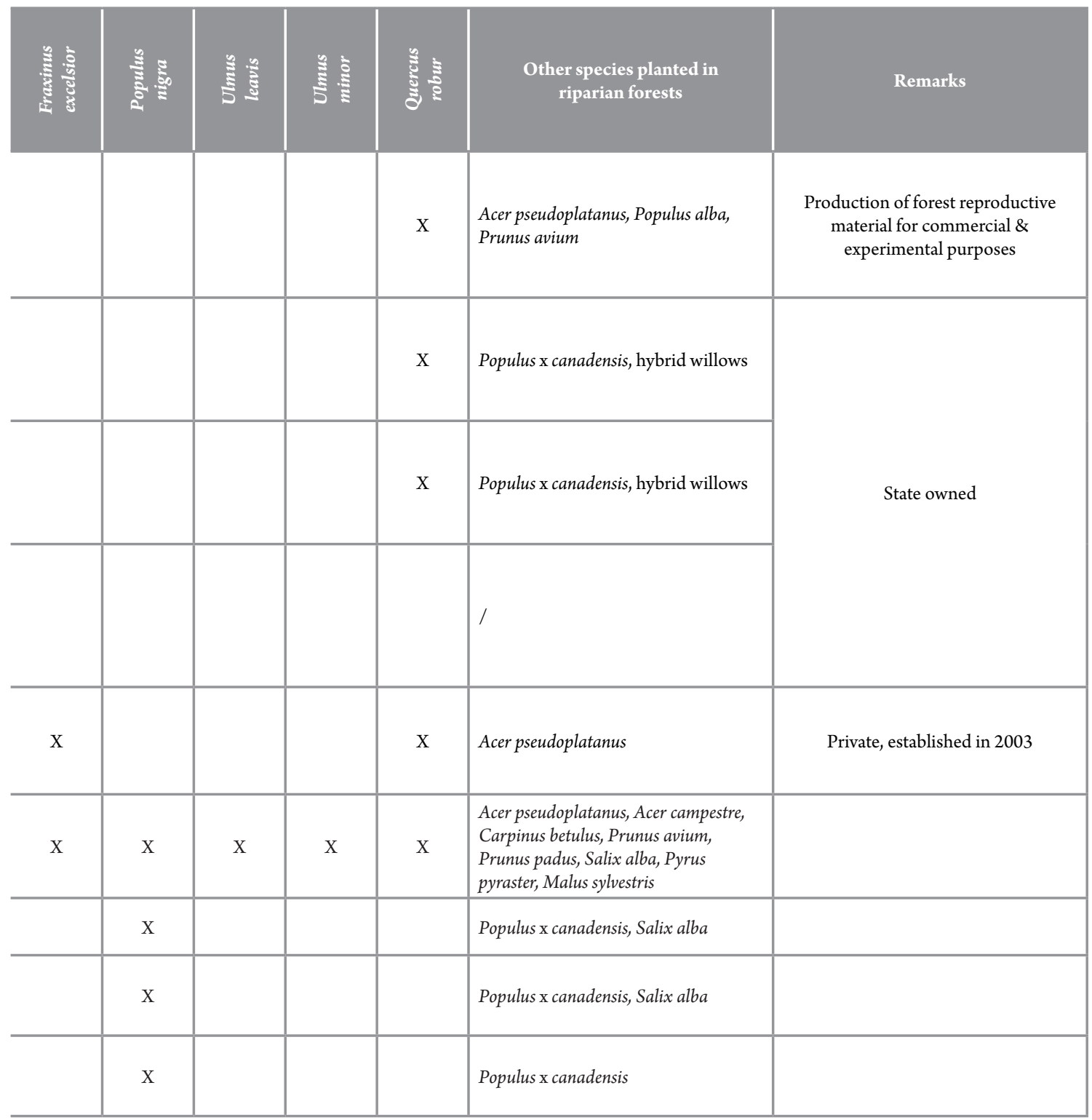




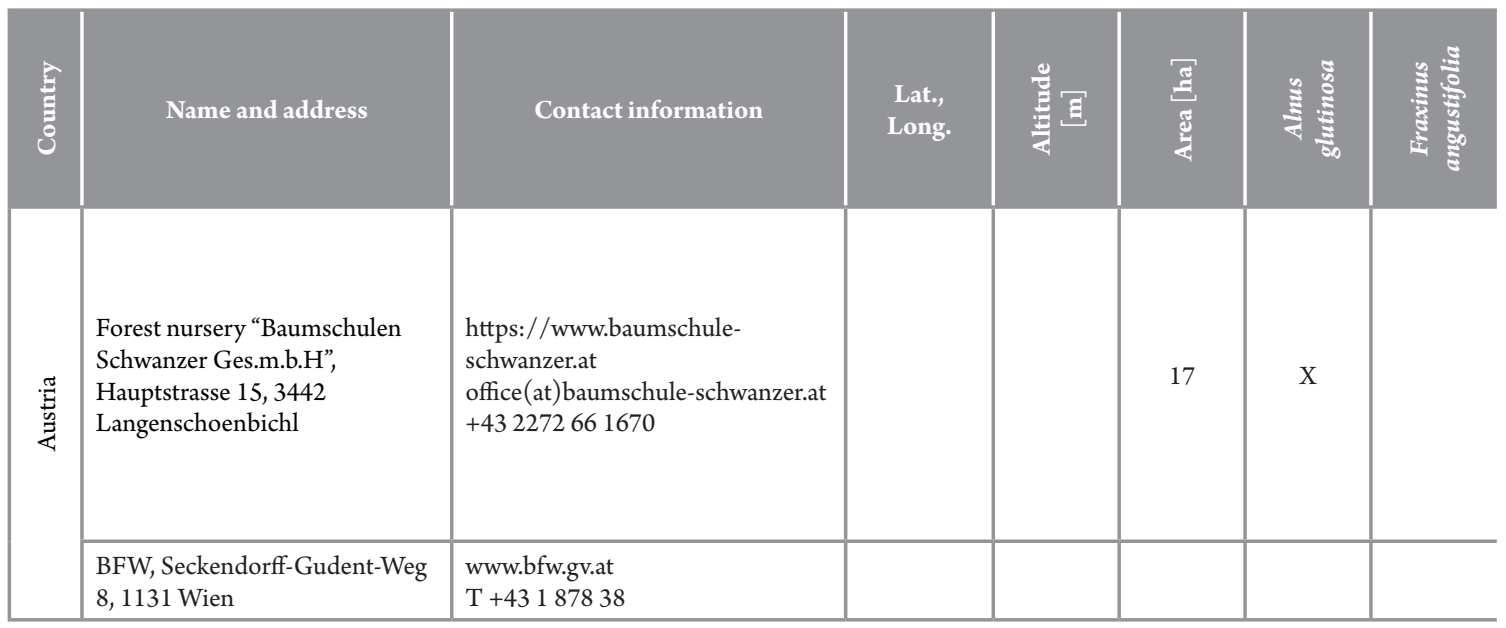




\begin{tabular}{c|c|c|c|c|c|c|}
\hline & $\mathrm{X}$ & $\mathrm{X}$ & $\begin{array}{l}\text { Other species planted in } \\
\text { riparian forests }\end{array}$ & Remarks \\
\hline $\mathrm{X}$ & $\mathrm{X}$ & $\mathrm{X}$ & $\begin{array}{l}\text { Acer pseudoplatanus, Acer campestre, } \\
\text { Carpinus betulus, Malus sylvestris, } \\
\text { Prunus avium, Pyrus pyraster, Populus } \\
\text { alba, Populus tremula, Populus } \mathrm{x} \\
\text { canadensis, Salix alba, Salix viminalis, } \\
\text { Salix fragilis, Salix purpurea, } \\
\text { Salix caprea, Salix cinerea, Tilia } \\
\text { cordata, Tilia platyphillos, Robinia } \\
\text { pseudoacacia, Robinia pseudoacacia } \\
\text { hybrides, Quercus rubra, Juglans nigra }\end{array}$ & $\begin{array}{c}\text { Established in 1948. Oak seeds were } \\
\text { collected in approved Forest Seed } \\
\text { Stand Murska šuma, Slovenia }\end{array}$ \\
\hline $\mathrm{X}$ & & & & \\
\hline
\end{tabular}




\section{References}

1. Eleršek L (1985) Morphological and physiological properties of forest seedlings. Project Report. Inštitut za gozdno in lesno gospodarstvo pri Biotehniški fakulteti, Ljubljana. http://eprints.gozdis.si/1638/

2. FAO (1983) A guide for collecting, extracting, cleaning, and storing the seed and for treatment to promote germination of dry-zone acacias. FAO, http://www.fao.org/3/q2190e/Q2190E00.htm\#TOC

3. Forest tree seedlings (1999) Forestry Commision. https://www.forestresearch.gov.uk/ documents/6591/FCBU121.pdf Accessed 20.03.2021

4. Herman - Planinšek M (2020) Protokol za vzgojo sadik hrasta doba in črne jelše / Protocol for the cultivation of oak and black alder seedlings. Tree nursery Drevesnica Omorika d.o.o., $1 \mathrm{p}$.

5. Ivetić V (2018) Reforestation challenges 2018. Reforesta 5:1-3 https://doi.org/10.21750/REFOR.5.01.47

6. Jakobović H (2019) Umjetnost uzgoja biljaka iz vode poput Babilonskih vrtova. Hrvatske šume 271-272: 38-39 (in Croatian)

7. Kraigher H (2020) Semenarski praktikum, Prenovljena in ilustrirana izdaja. Slovenian Forestry Institute, Silva Slovenica publishing centre, Ljubljana (in Slovene)

8. Duryea ML, Dougherty PM (ed.) (1990) Forest regeneration manual. Kluwer Academic Publishers, https://rngr.net/publications/forest-regeneration-manual Accessed 6.1.2021

9. Medved M, Bajc M, Božič G et al. (2013) Gospodarjenje z gozdom za lastnike gozdov / Forest management for forest owners. Kmečki glas, Ljubljana (in Slovene)

10. OECD Forest Seed and Plant Scheme (2018) http://www.oecd.org/agriculture/forest

11. Slovenia Forest Service (2019) Protocol on the management of forest tree seedlings from excavation in the nursery to their planting in the forest in cases where the seedlings are provided by the Slovenian Forest Service from the budget of the Republic of Slovenia (in Slovene)

12. Grossnickle SC, Yousry AE (2015) Bareroot versus container stock types: a performance comparison. New forests. https://doi.org/10.1007/s11056-015-9476-6

13. Suszka B, Muller C, Bonnet-Masimbert M (1996) Seeds of forest broadleaves, from harvest to sowing. INRA editions

14. Kraigher H, Brus R, Batič F (2011) Technical Guidelines for Genetic Conservation and Use: Alnus glutinosa, Alnus incana, Alnus. Gozdarski vestnik, 69: 475-484 (in Slovene)

15. EUFORGEN. Populus nigra identification sheet. http://www.euforgen.org/fileadmin/templates/ euforgen.org/upload/Publications/Other PDFs/Pop nigra IdSheets/English.pdf Accessed 20.03.2021

16. Commission implementing regulation (EU) 2018/1981 https://eur-lex.europa.eu/legal-content/EN/ TXT/PDF/?uri=CELEX:32018R1981\&rid=3 Accessed 20.03.2021 



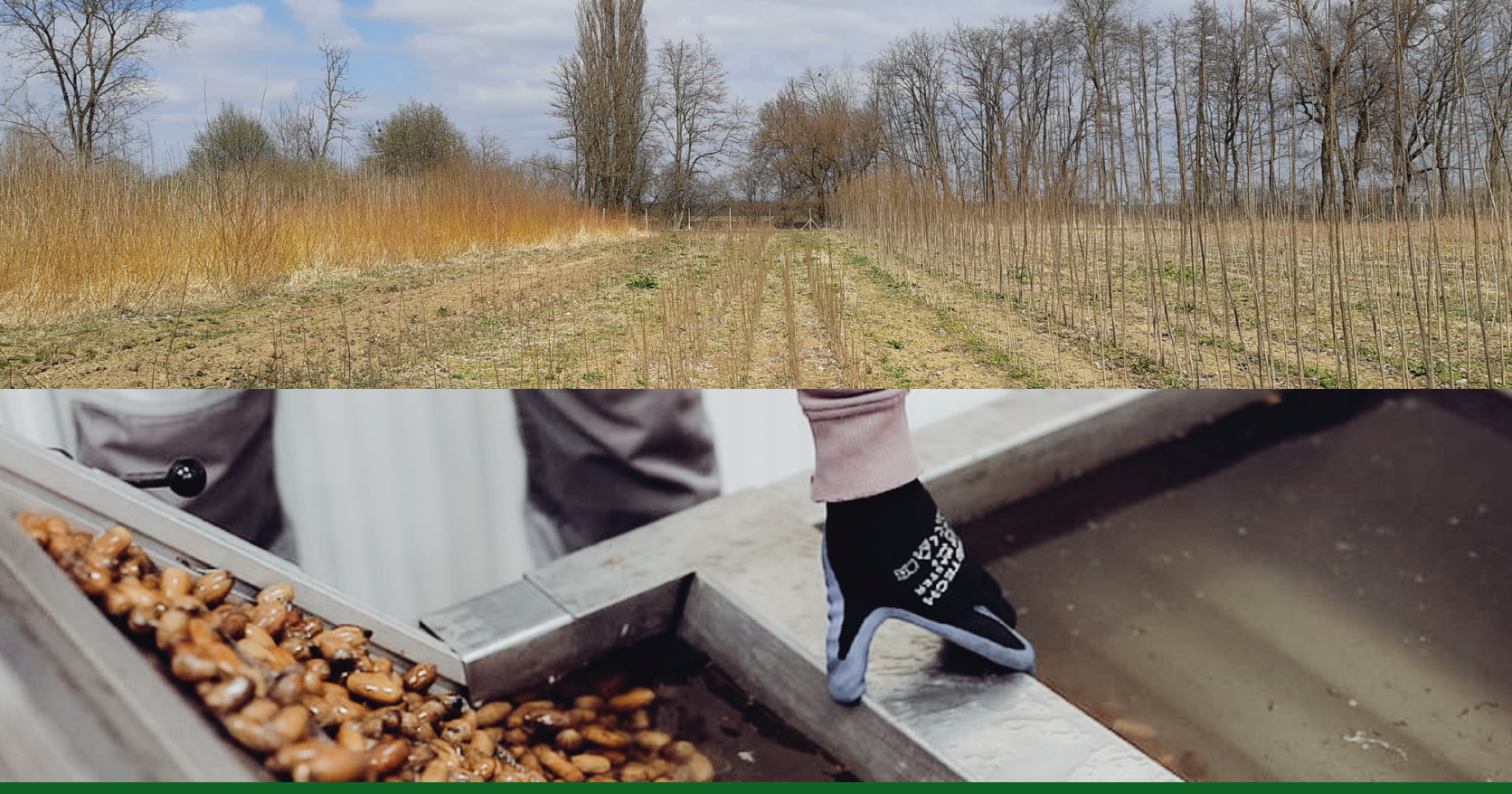

Riparian forests are among the most dynamic and threatened forests in Europe. In the Mura-DravaDanube Biosphere Reserve, their natural regeneration is often impaired or even impossible because the very dense ground cover vegetation on large areas may prevent regeneration from seed. Alternatively, the process may take too long in an intermittently flooded terrain. Therefore, natural regeneration of riparian forests is often supplemented by artificial regeneration.

These guidelines provide guidance on the selection of seed sources, seed collection and processing, promotion of genetic diversity, and good nursery conditions for the production of forest reproductive material for riparian forests to ensure sustainable regeneration, afforestation, or habitat restoration. They were developed based on scientific evidence and years of experience of forest nurseries located in and around Mura-Drava-Danube Biosphere Reserve. The guidelines also provide a unique insight into the forest nursery sector: the development, the costs, the daily work and the problems.

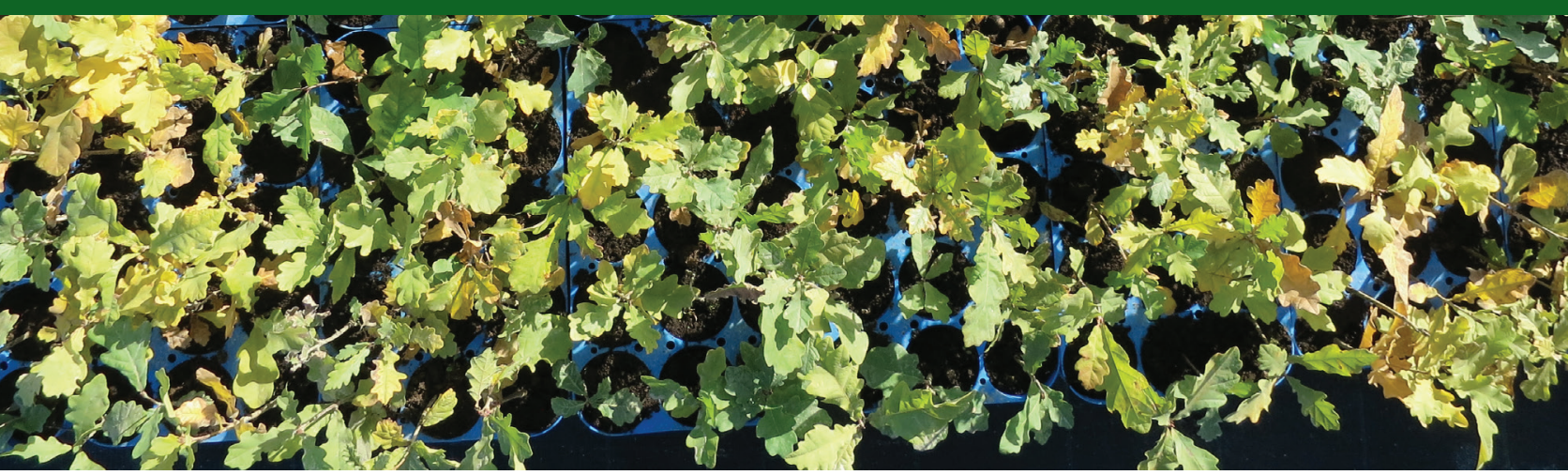

